\title{
Description of basement volcanic sequences in Holes U1342A and U1342D on Bowers Ridge in the Bering Sea ${ }^{1}$
}

\author{
H. Kawabata, ${ }^{2}$ K. Sato ${ }^{2}$ Y. Tatsumi, ${ }^{2}$ D.W. Scholl, ${ }^{3,}{ }^{4}$ K. Takahashi, ${ }^{5}$ and the Expedition 323 Scientists $^{6}$
}

\section{Chapter contents}

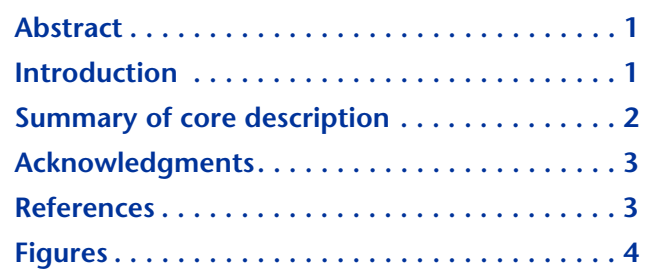

${ }^{1}$ Kawabata, H., Sato, K., Tatsumi, Y., Scholl, D.W., Takahashi, K., and the Expedition 323 Scientists, 2011. Description of basement volcanic sequences in Holes U1342A and U1342D on Bowers Ridge in the Bering Sea. In Takahashi, K., Ravelo, A.C., Alvarez Zarikian, C.A., and the Expedition 323 Scientists, Proc. IODP, 323: Tokyo (Integrated Ocean Drilling Program Management International, Inc.). doi:10.2204/iodp.proc.323.110.2011

${ }^{2}$ Institute for Research on Earth Evolution, Japan Agency for Marine-Earth Science and Technology, 2-15 Natsushima-cho, Yokosuka, Kanagawa 2370061, Japan. Correspondence author: hiroshik@jamstec.go.jp

${ }^{3}$ Department of Geology and Geophysics, University of Alaska Fairbanks, Fairbanks AK 99775, USA.

${ }^{4}$ Contact address: MS 999, U.S. Geological Survey, Menlo Park CA 90425, USA.

${ }^{5}$ Department of Earth and Planetary Sciences, Kyushu University, Hakozaki 6-10-1, Higashi-ku, Fukuoka 812-8581, Japan.

${ }^{6}$ Expedition 323 Scientists' addresses.

\section{Abstract}

At Ulm Plateau, near the eastern end of the crestal area of Bowers Ridge, basement of lithified volcaniclastic sediment $(\sim 42 \mathrm{~m})$ was recovered at Integrated Ocean Drilling Program (IODP) Site U1342 beneath a thin cover $(\sim 49 \mathrm{~m})$ of surface sediment. Recovery of basement rock provided an unprecedented opportunity to address the origin and evolution of this enigmatic appendage of the Aleutian arc massif. Contrasting hypotheses have been proposed for the formation of the arc massif of Bowers Ridge, either in the Cretaceous North Pacific Ocean exotic to the Bering Sea or within the Bering Sea during the Eocene formation of the Aleutian arc.

The volcanic sequence recovered from Site U1342 was divided into six major lithologic units: Unit I, vesiculated andesitic lava flow; Unit II, interbedded volcanic sandstone and polymict volcanic conglomerate; Unit III, monomict volcanic conglomerate; Unit IV, interbedded volcanic sandstone and polymict volcanic conglomerate; Unit V, monomict volcanic conglomerate; and Unit VI, polymict volcanic conglomerate. Units III and IV represent hydroclastic volcaniclastic deposits, whereas Units II, IV, and VI are epiclastic volcaniclastic strata.

\section{Introduction}

Bowers Ridge extends northward into the Bering Sea from the midpoint of the Aleutian Ridge and then sweeps westward in a recurving arc back toward the ridge. The dimensions of Bowers Ridge are large. Its curved length is $\sim 800 \mathrm{~km}$, and, where attached to the north side of the Aleutian arc massif, the ridge is nearly 200 $\mathrm{km}$ wide. At this junction, the ridge rises $\sim 3500 \mathrm{~m}$ above the abyssal floor of the Bering Sea Basin to flatten at a wave-planed summit platform at $\sim 600-1000 \mathrm{~m}$ water depth. The ridge's width and height decrease progressively with distance to the west.

Marine geophysical data establish that a $\sim 20-25 \mathrm{~km}$ thick core of basement rock constructs the bulk of Bowers Ridge (Cooper et al., 1981, 1987, 1992). Its middle and lower flanks are draped by a mantle of sedimentary deposits as thick as $2 \mathrm{~km}$. The ridge's magnetic, velocity, and gravity characteristics are typical of an arc massif. A sediment-buried trench at the base of the ridge's northern flank implies that the arc-generating subduction zone dipped southward beneath Bowers Ridge. 
Confirming the ridge's arc origin, in 1970 the R/V Melville dredged altered volcaniclastic sediment of calc-alkaline affinity from the ridge's upper, northern flank (Scholl et al., 1975; Scholl, 2007). The dredge site is located near Integrated Ocean Drilling Program (IODP) Site U1342. In 2009, west of Site U1342, the R/V Sonne dredged similar material from exposed basement also along the ridge's northern flank.

At Site U1342, a total of $41.54 \mathrm{~m}$ of basement rock was recovered from the southern side of Ulm Plateau, a subsided, $\sim 800 \mathrm{~m}$ deep wave-eroded platform. For the entire Aleutian-Bowers arc massif, no similar vertical sequence of its submerged arc framework exists. The recovered basement is evidently from a former ridge-cresting volcanic edifice demolished by subaerial and wave-base erosion in the late Miocene. Aboard the R/V JOIDES Resolution, the now vanished edifice was informally named Whiskey Mountain.

Two contrasting hypotheses have been proposed for the origin and evolution of the Bowers arc massif. The first is that, in the Late Cretaceous, Bowers Ridge formed in the Pacific Basin well to the south of its present location (Ben-Avraham and Cooper, 1981; Seliverstov, 1984). The second conjecture states that Bowers Ridge began to form within the Bering Sea region as an Eocene, in situ construct (Scholl et al., 1975; Scholl, 2007; Ben-Avraham and Cooper, 1981). The age, paleolatitude, geochemical, and petrologic analyses of the unprecedented recovery of a vertical section of basement rock at Site U1342, presumably from an erosionally decapitated and deeply submerged arc volcano, will determine which hypothesis is most correct or that neither is correct.

\section{Summary of core description}

This paper describes the cored volcanic section recovered during IODP Expedition 323 from Holes U1342A and U1342D. In the description, we used the nongenetic terms of volcanic conglomerate and volcanic sandstone (Suthren, 1985) instead of lapilli tuff, tuff breccia, and volcanic breccia. Mineral abundances in the igneous rocks were determined by point counting using 1000 points per thin section.

The volcanic sequence in Cores 323-U1342D-7X through $19 \mathrm{X}$ was divided into six major lithologic units as described below. Figure F1 schematically shows the lithology of the material recovered in Cores 323-U1342D-7X through 19X.

Unit $\mathrm{I}$ is a vesiculated andesitic lava flow that was recovered in Sections 323-U1342D-7X-1 through 8X-1 (Figs. F2, F3). A comparable lithology appears in
Core 323-U1342D-9X in Hole U1342A (Fig. F4). The andesite contains phenocrysts $(\sim 20-30$ vol\%) of magnetite $(\mathrm{Mt})$, orthopyroxene $(\mathrm{Opx})$, clinopyroxene $(\mathrm{Cpx})$, and plagioclase $(\mathrm{Pl})$ and has a groundmass showing intersertal texture. It also contains ellipsoidal vesicles $<7 \mathrm{~mm}$ long. This unit has a minimum thickness of $0.9 \mathrm{~m}$. The Unit I/II boundary was not recovered.

Unit II consists of interbedded volcanic sandstones and polymict volcanic conglomerates. These were recovered in Cores 323-U1342D-8X through 10X (Figs. F3, F5, F6). Volcanic clasts in the conglomerates and gravel sandstones are mainly angular to subangular fragments of basalts and andesites. The clasts have various phenocryst assemblages, phenocryst proportions, extent of vesiculation, and groundmass textures. For example, the following clasts are observed: olivine (OL)-Cpx-Pl porphyritic basalt, Cpx-Pl porphyritic basalt, Pl-sparsely phyric basaltic andesite, and aphyric basaltic andesite. Sandstones and the matrix of conglomerates consist of basaltic and andesitic fragments, together with mineral grains of pyroxene, plagioclase, and magnetite. Biogenic material is absent. The bedding planes of this unit have dips of $0^{\circ}$ to $10^{\circ}$. The unit has a minimum thickness of $8 \mathrm{~m}$. The base of this unit gradually changes to Unit III, which is monomict volcanic conglomerate.

Unit III is formed by monomict volcanic conglomerates, which are observed in Cores 323-U1342D-10X and 11X (Figs. F6, F7). Clasts in the conglomerates are made up of aphyric basalt, in which there are phenocrysts ( $<3 \mathrm{vol} \%)$ of clinopyroxene and plagioclase and glassy to intersertal groundmass. Clasts are an average of $\sim 1.5 \mathrm{~cm}$ in size, with a maximum size of $>6 \mathrm{~cm}$. The matrix is basically composed of fineto medium-sized altered glass of the same basalt as that making up the clasts. The minimum thickness of this unit is $6.5 \mathrm{~m}$. The presence of radial cooling joints in large basaltic clasts and the cognate origin of the clasts and the glassy matrix suggest that this unit is probably hydroclastic volcaniclastics (e.g., Suthren, 1985).

Unit IV consists of interbedded volcanic sandstones and polymict volcanic conglomerates. This unit appears in Cores 323-U1342D-11X through 14X (Figs. F7, F8, F9, F10). The sandstones and the matrix of the polymict conglomerates are composed of various types of volcanic fragments. Because large amounts of reddish sand are included in this unit compared to Unit II, the sandstone and matrix of the conglomerate are dark red to reddish gray in color. Clasts in the conglomerate are angular to subangular basaltic and andesitic pebbles. This unit is characterized by the presence of fault and slump structures. The fault 
planes have dips of $\sim 85^{\circ}$ and displacements of $\sim 7 \mathrm{~cm}$. This unit is $9.5 \mathrm{~m}$ thick. There is a sharp contact between the base of this unit and the top of Unit V.

Unit V is comprised of monomict volcanic conglomerates recovered from Core 323-U1342D-14X (Fig. F10). Clasts are angular to subangular vesiculated basalt. The clasts reach $7 \mathrm{~cm}$ in size, with an average size of $1 \mathrm{~cm}$. The basalt clasts contain phenocrysts (less than $\sim 10 \mathrm{vol} \%$ ) of completely altered olivine, clinopyroxene, and plagioclase, and exhibit variable vesiculation up to $\sim 15 \mathrm{vol} \%$. The matrix consists of very fine fragments of glassy basaltic material, which is the same as the clasts. The minimum thickness of this unit is $1 \mathrm{~m}$. This unit is probably hydroclastic volcaniclastics. The Unit V/VI boundary was not recovered.

Unit VI consists of polymict volcanic conglomerates recovered from Cores 323-U1342D-15X through 19X (Figs. F11, F12, F13, F14, F15). Clasts are angular to subangular and consist of various types of basalts to andesites. The most abundant type of clasts is a highly porphyritic basalt (consisting of $\sim 30-40 \mathrm{vol} \%$ phenocrysts) with phenocrysts of altered olivine, clinopyroxene, plagioclase, and minor orthopyroxene. The basaltic clasts have variable vesicularities up to $\sim 15 \mathrm{vol} \%$. The matrix of the clasts is made up of medium-grained to very coarse grained basaltic and andesitic fragments together with plagioclase and pyroxene grains. Depending on the fraction and size of the clasts, four subunits are recognized. The boundaries between the subunits are gradual. The lower three subunits are characterized by normal grading of clasts. The minimum thickness of this unit is $18 \mathrm{~m}$.

\section{Acknowledgments}

We thank all the members of Integrated Ocean Drilling Program (IODP) Expedition 323 to the Bering Sea including the Captain, crew, drilling engineers, technicians, and those who assisted Expedition 323 on shore, including the team at Texas A\&M University (TAMU), Ocean Leadership, and the National Science Foundation, for their able cooperation throughout, before, during, and after the cruise. Special thanks are expressed to the drilling team, including Stephen Midgley of IODP-TAMU and Joe "Bubba" Attryde of
Transocean, who made the successful recovery of the volcanic sequence by proceeding with the extended core barrel technique rather than employing the rotary core barrel technique within the limited time that could be allocated for basement drilling of $\sim 24 \mathrm{~h}$.

\section{References}

Ben-Avraham, Z., and Cooper, A.K., 1981. Early evolution of the Bering Sea by collision of oceanic rises and North Pacific subduction zones. Geol. Soc. Am. Bull., 93(7):485495. doi:10.1130/00167606(1981)92<485:EEOTBS>2.0.CO;2

Cooper, A.K., Marlow, M.S., and Ben-Avraham, Z., 1981. Multichannel seismic evidence bearing on the origin of Bowers Ridge, Bering Sea. Geol. Soc. Am. Bull., 92(7):474-484. doi:10.1130/00167606(1981)92<474:MSEBOT>2.0.CO;2

Cooper, A.K., Marlow, M.S., and Scholl, D.W., 1987. Geologic framework of the Bering Sea crust. In Scholl, D.W., Grantz, A., and Vedder, J.G. (Eds.), Geology and Resource Potential of the Continental Margin of Western North America and Adjacent Ocean Basins-Beaufort Sea to Baja California. Earth Sci. Ser., 6:73-102.

Cooper, A.K., Marlow, M.S., Scholl, D.W., and Stevenson, A.J., 1992. Evidence for Cenozoic crustal extension in the Bering Sea region. Tectonics, 11(4):719-731. doi:10.1029/92TC00214

Scholl, D.W., Buffington, E.C., and Marlow, M.S., 1975. Plate tectonics and the structural evolution of the Aleutian-Bering Sea region. Spec. Pap.-Geol. Soc. Am., 151:131.

Scholl, D.W., 2007. Viewing the tectonic evolution of the Kamchatka-Aleutian (KAT) connection with an Alaska crustal extrusion perspective. In Eichelberger, J., Gordeyev, Y., Izbekov, P., Kasahara, M., and Lees, J.M. (Eds.), Volcanism and Subduction: the Kamchatka Region. Geophys. Monogr., 172:3-35.

Seliverstov, N.I., 1984. Structure of junction zone between Kuril-Kamchatka and Aleutian Island Arc from continuous seismic profiling. Vulkanol. Seysmol., 3:53-67. (in Russian)

Suthren, R.J., 1985. Facies analysis of volcaniclastic sediments: a review. In Brenchley, P.J., and Williams, B.P.J. (Eds.), Sedimentology: Recent Developments and Applied Aspects. Geol. Soc. Spec. Publ., 18(1):123-146.

doi:10.1144/GSL.SP.1985.018.01.07

Publication: 15 March 2011

MS 323-110 
Figure F1. Lithology and core recovery of Cores 323-U1342D-7X through 19X.

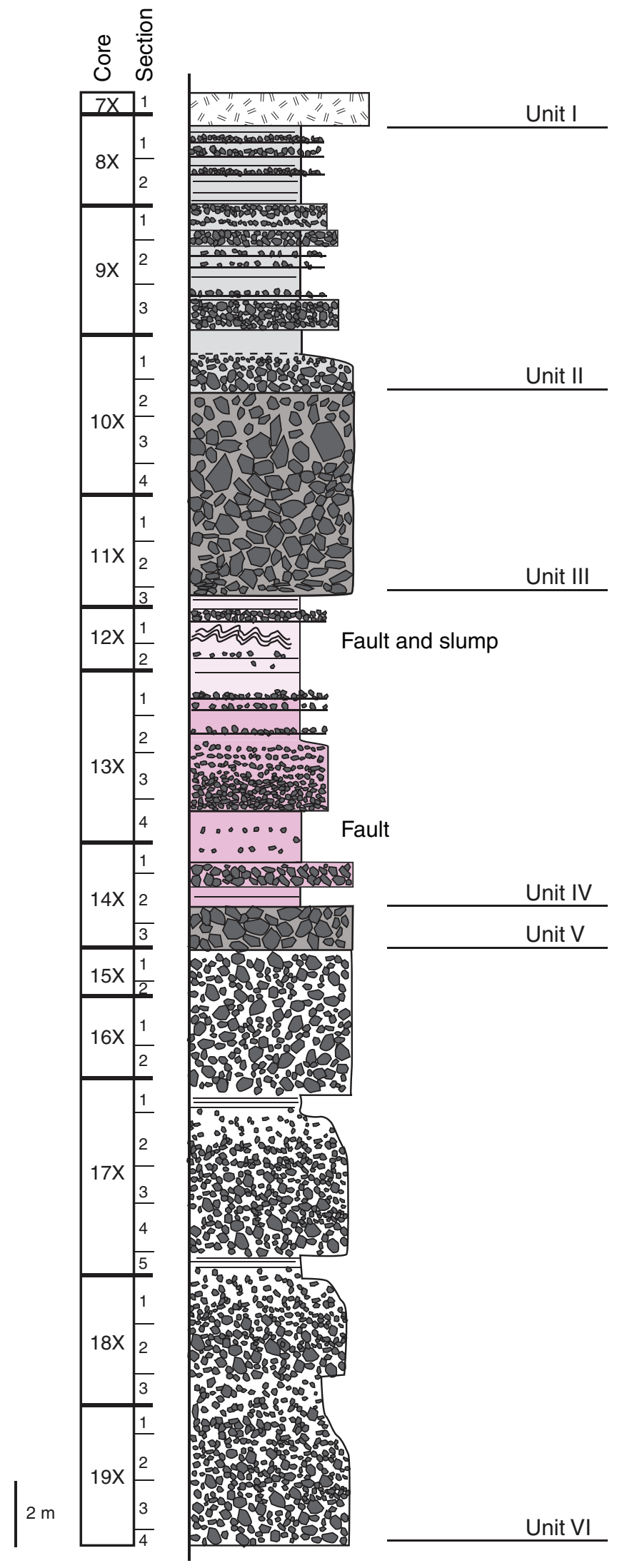


Figure F2. Description of Core 323-U1342D-7X.

\begin{tabular}{l} 
Section 323-U1342D-7X-1 \\
UNIT I, Andesitic lava flow \\
\hline
\end{tabular}

\section{COMMEMTS:}

This lithology is the same what appears in Section 323-U1342A9X-1, and continues downward to Section 323-U1342D-8X-1. 
Figure F3. Description of Core 323-U1342D-8X. (Continued on next page.)

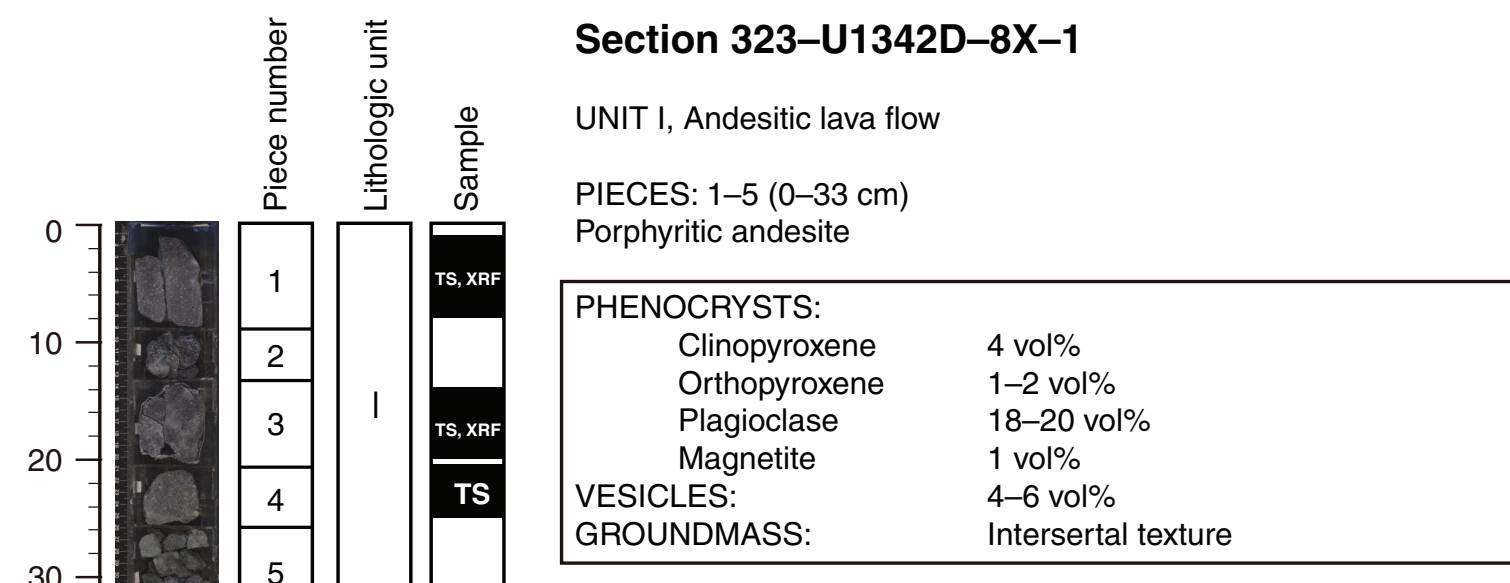

UNIT II, Interbedded volcanic sandstone and conglomerates

PIECES: 6-8 (33-56 cm)

Volcanic sandstone

GENERAL DESCRIPTION: Moderately sorted, medium to coarse sandstone. Minor lamination and scattered polymictic volcanic clasts $(<0.5 \mathrm{~cm})$ are present.

COLOR: Gray

PIECES: 9-10 (56-74 cm)

Volcanic sandy conglomerate

GENERAL DESCRIPTION: Stratified matrix-supported polymict sandy conglomerate. Angular to sub-angular volcanic clasts ( $\max$ $1.5 \mathrm{~cm}$, ave. $0.5 \mathrm{~cm}$ ) in a matrix of fine sandstone.

COLOR: Matrix is gray. Clasts are gray, yellowish gray, pale purple, and red.

PIECES: $11-20(74-120 \mathrm{~cm})$

Volcanic sandstone

GENERAL DESCRIPTION: Medium to coarse sandstone. Minor lamination is present throughout this sub-unit. Sub-angular volcanic clasts $(<0.5 \mathrm{~cm})$ are scattered.

COLOR: Black to dark gray

PIECES: 20-22 (120-143 cm)

Volcanic conglomerate

GENERAL DESCRIPTION: Massive clast-supported polymict conglomerate. Angular to sub-angular lithic clasts ( $\max 1.5 \mathrm{~cm}$ and ave. $0.5 \mathrm{~cm}$ ) are present in the matrix of medium to very coarse sand. Clasts are aphyric to porphyritic basalts and andesites, and show variable vesicularity (0-30 vol\%) and groundmass textures (glassy, hyalo-ophitic, and intersertal). Phenocrysts are plagioclase +/- clinopyroxene +/- altered olivine +/- magnetite. The contact between this sub-unit and the upper sandstone is sharp. The matrix consists of andesitic to basaltic fragments and crystals.

COLOR: Varies. Clasts are black, gray, yellowish gray, pale purple, and red.

PIECE: $23(143-150 \mathrm{~cm})$

Gray fine sandstone 
Figure F3 (continued).

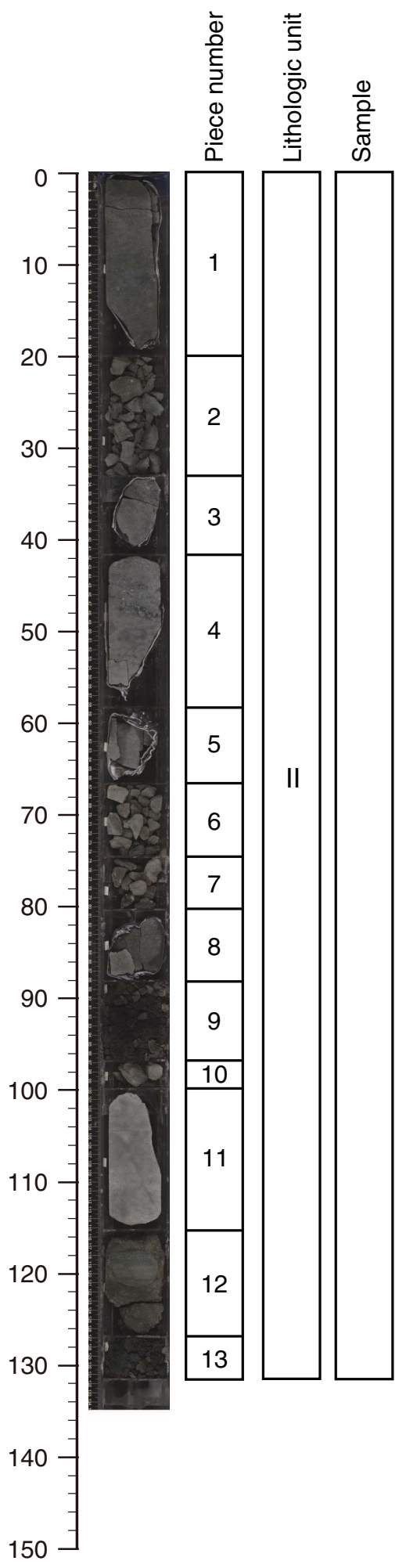

\section{Section 323-U1342D-8X-2}

UNIT II, Interbedded volcanic sandstone and conglomerates

PIECES: $1-11(0-115 \mathrm{~cm})$

Volcanic sandstone

GENERAL DESCRIPTION: Moderately-sorted fine to medium sandstone. 0-42 cm, angular to sub-angular volcanic clasts $(0.3-0.7 \mathrm{~cm})$ are rarely included. $42-48 \mathrm{~cm}$, thin polymict conglomerate layers $(<1 \mathrm{~cm})$ are interbedded.

COLOR: Yellowish to dark gray

PIECE: 12 (115-127 cm)

Volcanic sandy conglomerate

GENERAL DESCRIPTION: Sub-angular volcanic clasts are present within dark gray fine to coarse sandstone. Although most of the clasts are less than $1 \mathrm{~cm}$, cobble sized $(\mathrm{ca} .6 \mathrm{~cm}$ ) rounded sandstones exhibiting lamination are also included.

PIECE: 13 (127-132 cm)

Mud and fragments of sandstone 
Figure F4. Description of Core 323-U1342A-9X.

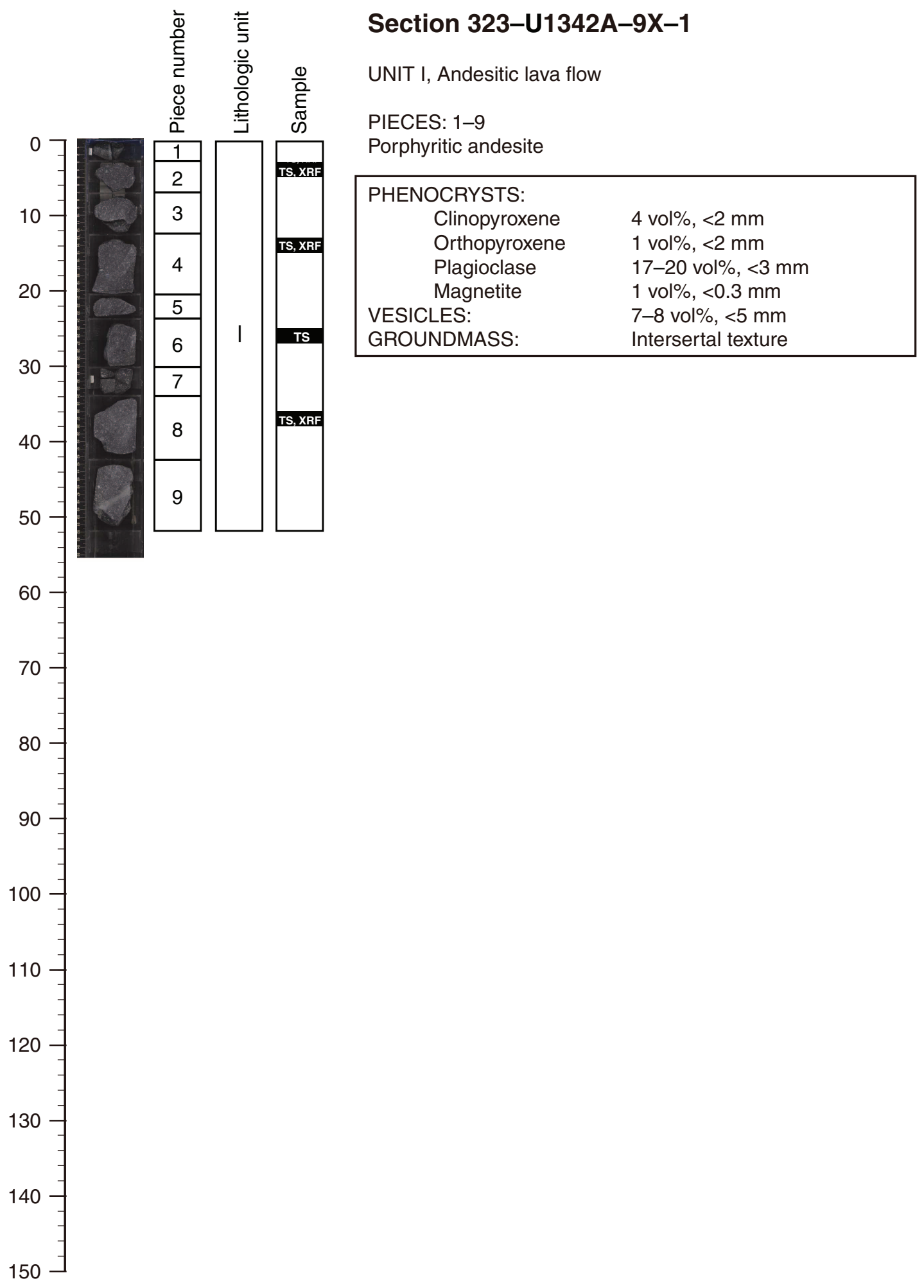


Figure F5. Description of Core 323-U1342D-9X. (Continued on next two pages.)

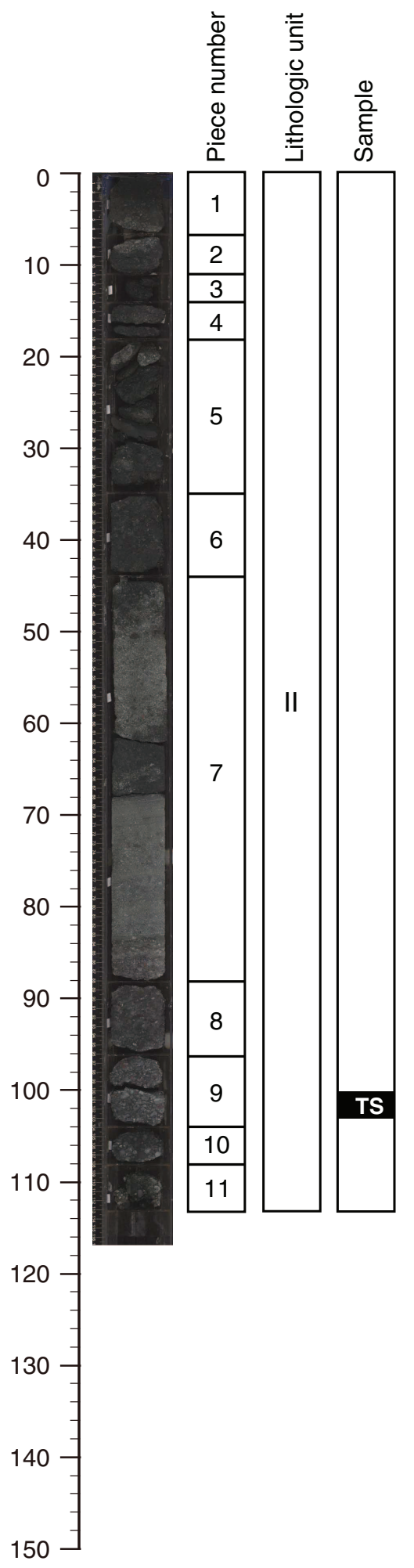

Section 323-U1342D-9X-1

UNIT II, Interbedded volcanic sandstone and conglomerates

PIECES: $1-7(0-68 \mathrm{~cm})$

Volcanic conglomerate

GENERAL DESCRIPTION: Massive to weakly stratified, matrixsupported polymict conglomerate and gravel sandstone. Lithic clasts are angular to sub-angular ( $\max 1.5 \mathrm{~cm}$, ave. $0.5 \mathrm{~cm}$ ).Grain size of matrix gradually changes from fine to medium sandstone ( 0 $-44 \mathrm{~cm})$ and medium to coarse sandstone $(44-68 \mathrm{~cm})$ towards bottom.

COLOR: Clasts show various colors such as black, gray, yellowish gray, pale green, pale purple, and red.

PIECE: 7 (68-84 cm)

Volcanic sandstone

GENERAL DESCRIPTION: Very coarse to fine sandstone with polymictic clasts ( $\max 1 \mathrm{~cm}$, ave $0.3 \mathrm{~cm}$ ). Lamination with a dip of ca. $10^{\circ}$ is well developed. The boundaries between this sub-unit and sub-units above and lower are sharp.

COLOR: Greenish gray

PIECES: 7-11 (84-113 cm)

Volcanic conglomerate

GENERAL DESCRIPTION: Clast-supported polymict conglomerate. Except for the weak lamination in upper $3 \mathrm{~cm}$, sedimentary structure is massive. Angular to sub-angular ( $\max 1.5 \mathrm{~cm}$, ave $1 \mathrm{~cm}$ ) lithic clasts are basaltic to andesitic. They have various phenocrysts, groundmass textures (glassy, hyalo-ophitic, intersertal, and intergranular), and vesicularities (0-50 vol\%). Phenocrysts are plagioclase +/- clinopyroxene +/- altered olivine +/- magnetite. Matrix is fine to coarse sandstone. This lithology continues downward to Section 323-U1342D-9X-2.

COLOR: Clasts show various colors such as gray, yellowish gray, greenish gray, pale purple, and red. 
Figure F5 (continued). (Continued on next page.)

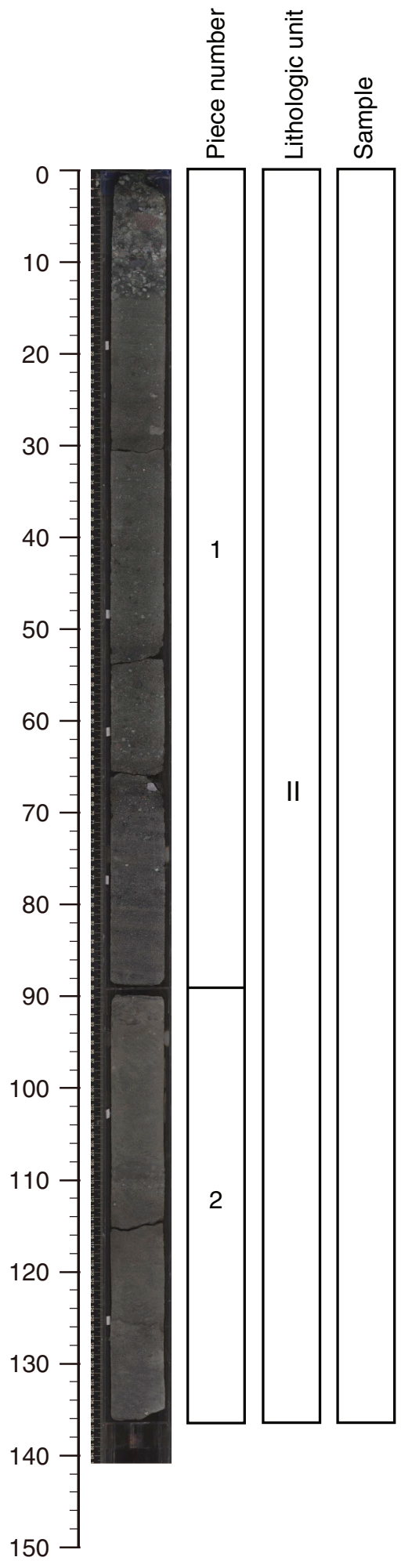

\section{Section 323-U1342D-9X-2}

UNIT II, Interbedded volcanic sandstone and conglomerates

PIECE: $1(0-14 \mathrm{~cm})$

Volcanic conglomerate

GENERAL DESCRIPTION: Massive clast-supported polymict conglomerate. Angular to sub-angular $(2.5 \mathrm{~cm}$ max and $1.5 \mathrm{~cm}$ ave) polymict lithic clasts are present in matrix of fine sandstone. Other lithological features are same as Section 323-U1342D-9X-1 $(84-113 \mathrm{~cm})$.

\section{PIECES: 1-2 (14-90 cm)}

Volcanic sandstone and conglomeratic sandstone GENERAL DESCRIPTION: Moderately sorted, fine to medium sandstone. This includes angular to sub-angular $(1 \mathrm{~cm}$ max and 0.5 $\mathrm{cm}$ ave) polymict lithic clasts. The clasts are most abundant between 51 and $70 \mathrm{~cm}$ (ca. 40 vol\%). Parallel lamination is developed throughout this sub-unit. Contacts between this sequence and the massive conglomerates above $(0-14 \mathrm{~cm})$ and the massive sandstone $(91-136 \mathrm{~cm})$ below are sharp.

COLOR: Gray

PIECE: 2 (90-136 cm)

Volcanic sandstone GENERAL DESCRIPTION: Grain size changes at $125 \mathrm{~cm}$.

Massive, well-sorted fine sandstone occurs from $90-125 \mathrm{~cm}$, while moderately sorted fine to medium sandstone from $125-136 \mathrm{~cm}$. This lithology continues downward to Section 323-U1342D-9X-3. COLOR: Brownish gray 
Figure F5 (continued).

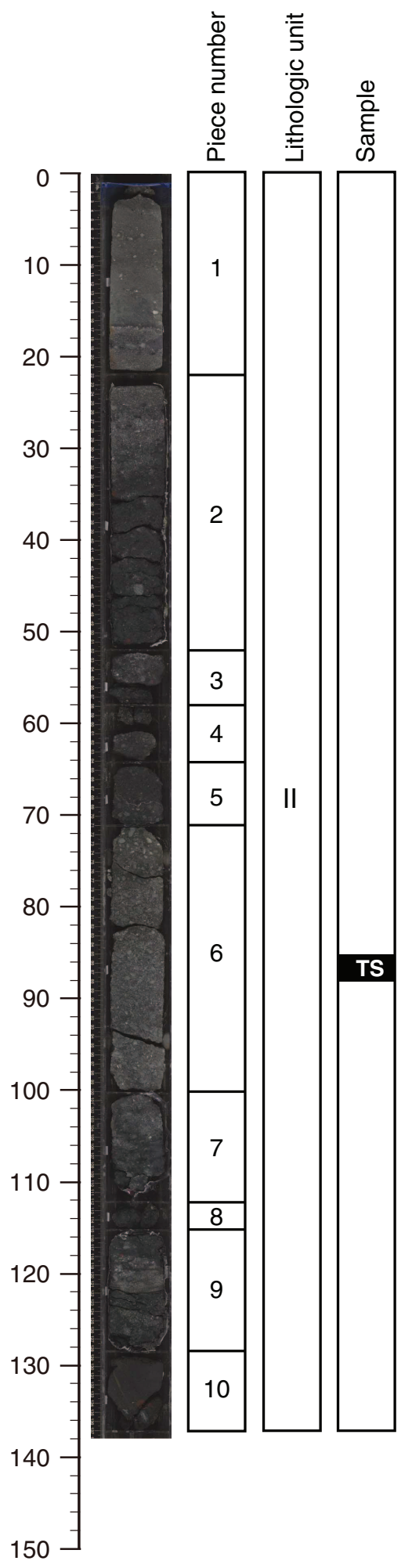

\section{Section 323-U1342D-9X-3}

UNIT II, Interbedded volcanic sandstone and conglomerates

PIECE: $1(0-16 \mathrm{~cm})$

Volcanic sandstone with lithic clasts

GENERAL DESCRIPTION: Weakly stratified, very coarse to

fine-grained sandstone with scattered lithic clasts. The clasts are angular to sub-angular and $<1 \mathrm{~cm}$ in size. The contact between this sub-unit and the lower conglomerate is sharp.

COLOR: Yellowish gray

\section{PIECES: 1-9 (16-128 cm)}

Volcanic conglomerate

GENERAL DESCRIPTION: Massive clast-supported polymict conglomerate. In the upper $5 \mathrm{~cm}$ thin coarse to very coarse sandstone layers are interbedded. Angular to sub-angular lithic clasts ( $\max 2 \mathrm{~cm}$ and ave $0.4 \mathrm{~cm}$ ) are in a matrix of very coarse to medium-grained sandstone. Clasts have various phenocrysts, groundmass textures (glassy, hyalo-ophitic, and intersertal), and vesicularities (0-30 vol\%). Phenocrysts are plagioclase +/- clinopyroxene +/- altered olivine +/- magnetite.

COLOR: Clasts show various colors such as gray, yellowish gray, greenish gray, pale purple, and red.

PIECE: 10 (129-137 cm)

Volcanic sandstone

GENERAL DESCRIPTION: Massive medium sandstone. This lithology continues downward to Section 323-U1342D-10X-1. COLOR: Dark gray 
Figure F6. Description of Core 323-U1342D-10X. (Continued on next three pages.)

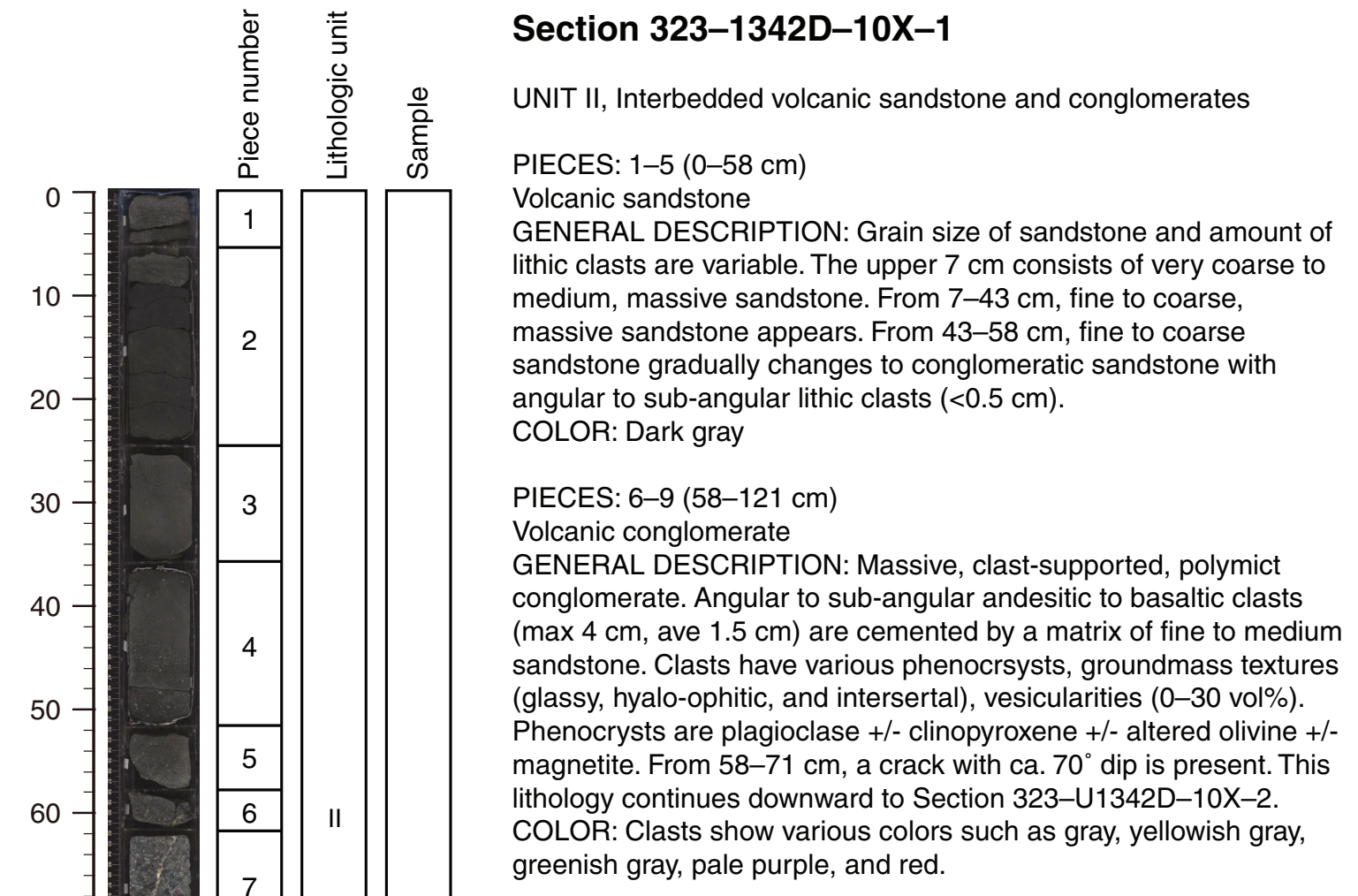


Figure F6 (continued). (Continued on next page.)

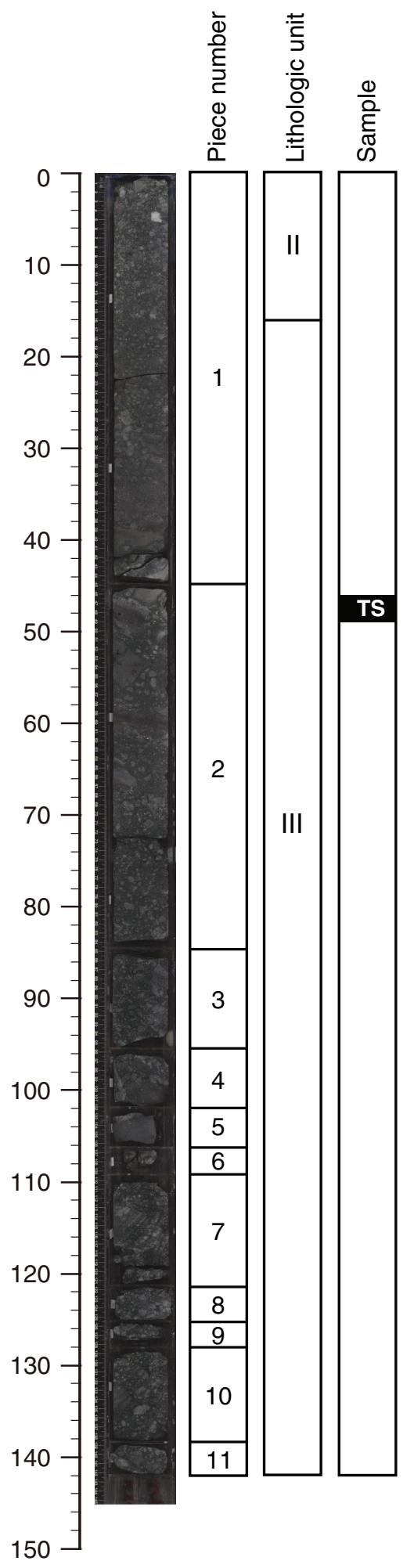

\section{Section 323-U1342D-10X-2}

UNIT II, Interbedded volcanic sandstone and conglomerates

PIECE: $1(0-41 \mathrm{~cm})$

Volcanic conglomerate

GENERAL DESCRIPTION: From 0-20 cm, massive, clast-

supported, polymict conglomerate appears. Lithic clasts are angular to sub-angular andesitic to basaltic fragments $(\max 2 \mathrm{~cm}$, ave 1.5 $\mathrm{cm}$ ). Matrix is fine to medium-grained sandstone. This polymict conglomerate gradually changes to Unit III, a monomict volcanic conglomerate through $20-41 \mathrm{~cm}$.

UNIT III, Monomict volcanic conglomerates

PIECES: 1-11 (41-142 cm)

Volcanic conglomerate

GENERAL DESCRIPTION: Massive, clast-supported monomict volcanic conglomerate. Lithic clasts are angular to sub-angular ( $\max >5 \mathrm{~cm}$, ave $2 \mathrm{~cm}$ ), vesiculated plagioclase and clinopyroxenebearing (ca. 1 vol\%) basalt. Groundmass texture is glassy through hyalo-ophitic to intersertal. Matrix is mainly composed of fragments of glass and basaltic clasts. From 25-64 cm, however, the matrix includes yellowish brown medium-grained sand, which is composed of altered glass, crystals (plagioclase, pyroxene, and magnetitie), and various types of andesitic to basaltic fragments. Some clasts show radial cooling joints.

COLOR: Clasts and matrix are dark gray to gray. 
Figure F6 (continued). (Continued on next page.)

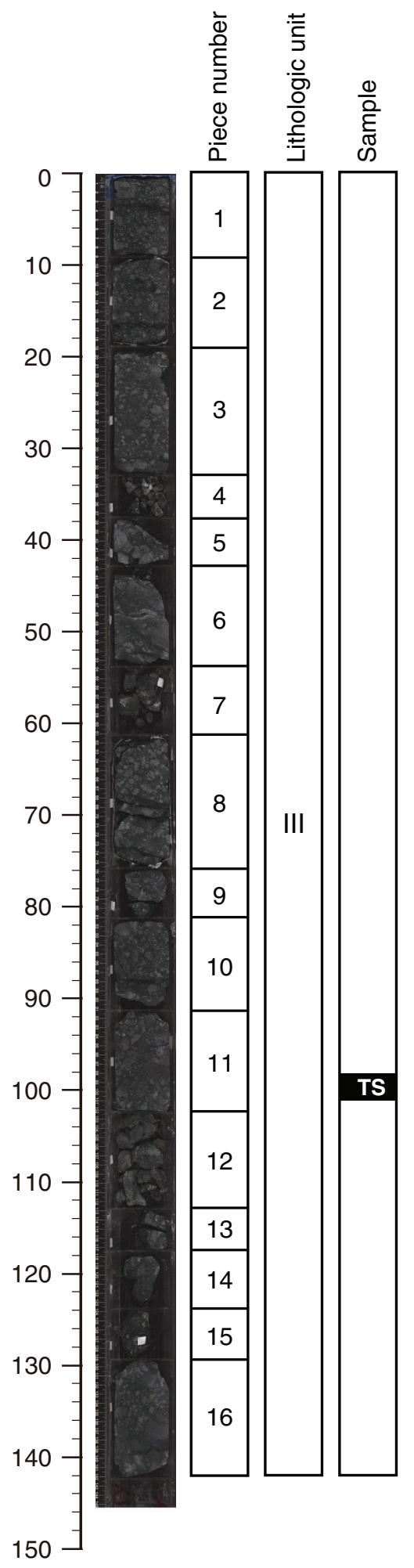

\section{Section 323-U1342D-10X-3}

UNIT III, Monomict volcanic conglomerates

PIECES: $1-16(0-142 \mathrm{~cm})$

Volcanic conglomerate

GENERAL DESCRIPTION: Massive, clast-supported monomict volcanic conglomerate. Lithic clasts are angular to sub-angular (max $>4 \mathrm{~cm}$, ave $1.5 \mathrm{~cm}$ ), vesiculated aphyric basalt. Phenocrysts are plagioclase and clinopyroxene. Groundmass shows glassy through hyalo-ophitic to intersertal texture. Matrix is mainly composed of fragments of basaltic clasts and altered glass. However, a fine to medium-grained sandstone layer, $1 \mathrm{~cm}$ in thickness, is present in the matrix at $47 \mathrm{~cm}$. This sandstone is same as that observed in Section 323-U1342D-10X-2 (25-64 cm). Below $47 \mathrm{~cm}$, the matrix is purely composed of cognate volcanic fragments.

COLOR: Clasts and matrix are dark gray to gray. 
Figure F6 (continued).

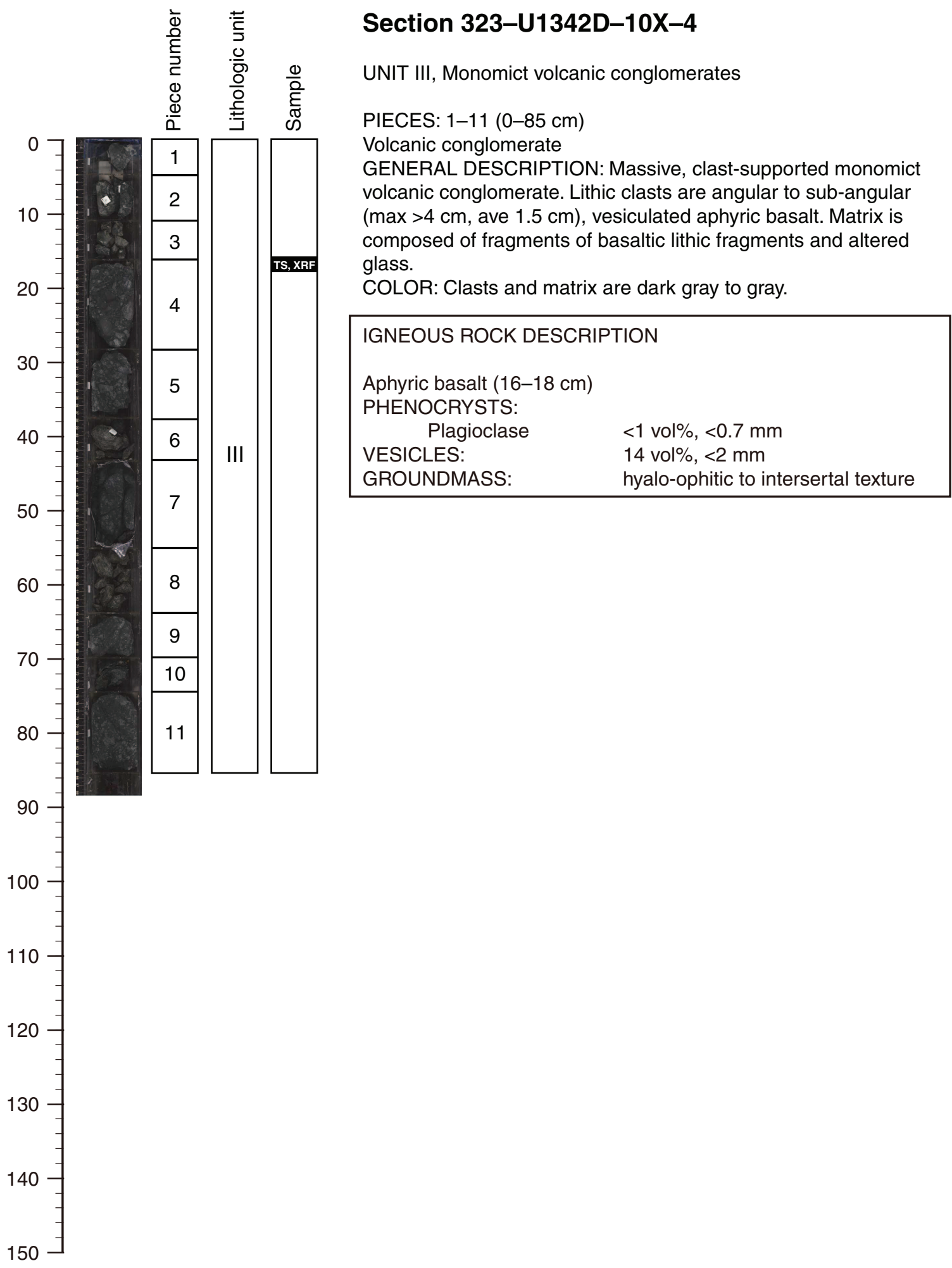


Figure F7. Description of Core 323-U1342D-11X. (Continued on next two pages.)

\begin{tabular}{l|l|l|l|l|l} 
Section 323-U1342D-11X-1 \\
UNIT III, Monomict volcanic conglomerates
\end{tabular}


Figure F7 (continued). (Continued on next page.)

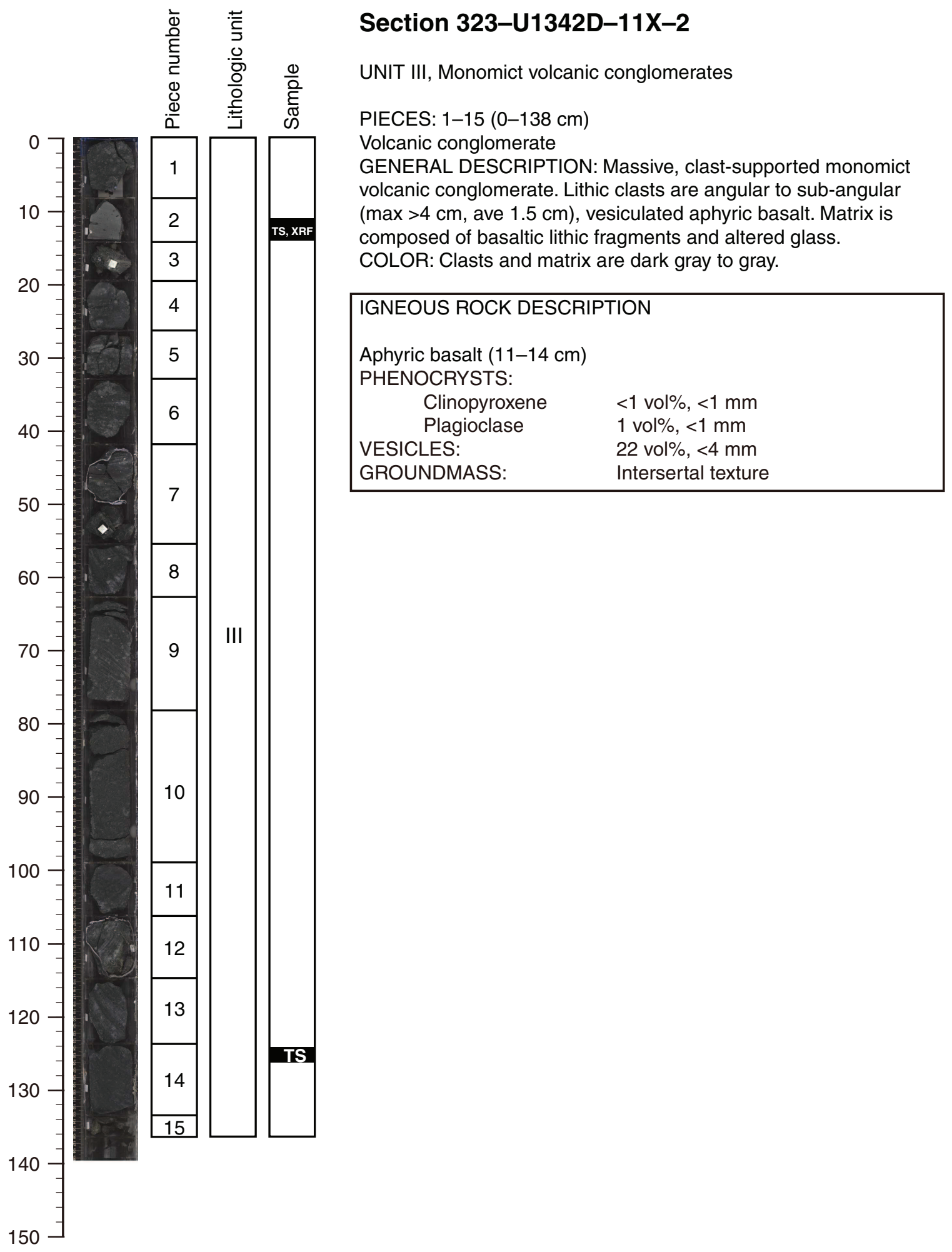


Figure F7 (continued).

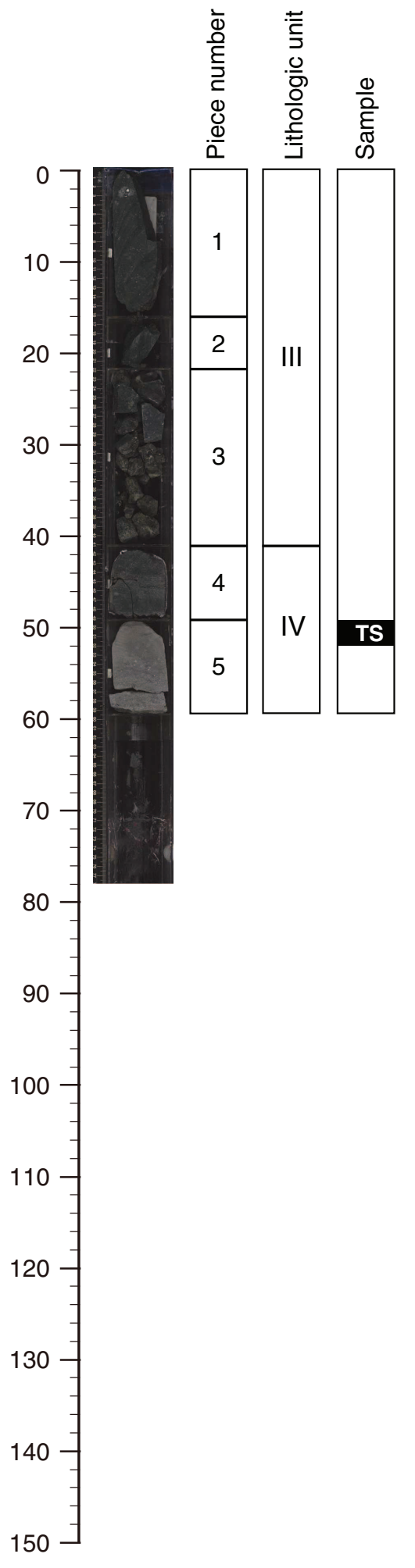

\section{Section 323-U1342D-11X-3}

UNIT III, Monomict volcanic conglomerates

PIECES: $1-3(0-41 \mathrm{~cm})$

Volcanic conglomerate

GENERAL DESCRIPTION: Massive, clast-supported monomict volcanic conglomerate. Lithic clasts are angular to sub-angular ( $\max >4 \mathrm{~cm}$, ave $1.5 \mathrm{~cm}$ ), vesiculated aphyric basalt. Matrix is composed of basaltic lithic fragments and altered glass.

COLOR: Clasts and matrix are dark gray to gray.

UNIT IV, Interbedded volcanic sandstone and conglomerates

PIECES: 4-5 (41-60 cm)

Volcanic sandstone

GENERAL DESCRIPTION: Piece 4 is a black, fine to mediumgrained sandstone. Parallel laminations are developed. In contrast, Piece 5 is a light gray fine to very coarse-grained sandstone. The sandstone is composed of basaltic to andesitic lithic fragments, altered glass, and crystals (e.g., plagioclase, clinopyroxene, and magnetite). The contact with the upper monomict conglomerate (Unit III) has not been recovered.

COLOR: Dark gray (Piece 4) and brownish gray (Piece 5) 
Figure F8. Description of Core 323-U1342D-12X. (Continued on next page.)

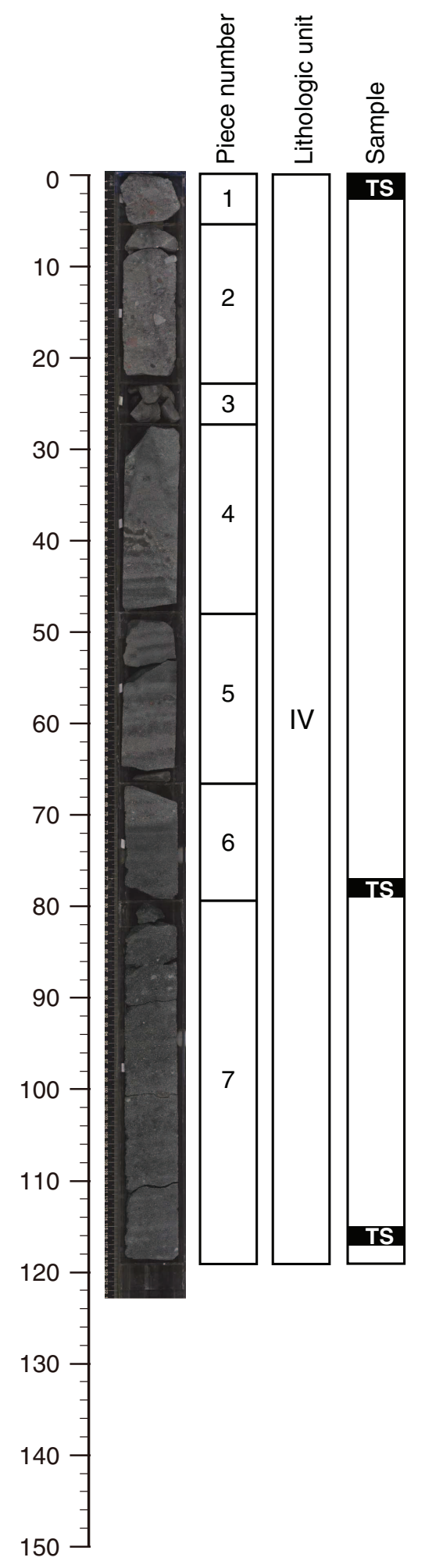

Section 323-U1342D-12X-1

UNIT IV, Interbedded volcanic sandstone and conglomerates

PIECES: 1-2 $(0-23 \mathrm{~cm})$

Volcanic sandy conglomerate

GENERAL DESCRIPTION: Massive matrix-supported sandy conglomerate. Angular to sub-angular basaltic to andesitic clasts ( $\max 2 \mathrm{~cm}$, ave $0.5 \mathrm{~cm}$ ) are vary in terms of phenocryst assemblage, groundmass textures (hyalo-ophitic, intersertal, and intergranular), and vesicularities (0-40 vol\%). Phenocrysts are plagioclase +/- clinopyroxene +/- altered olivine +/- magnetite. Color of clasts are variable, but purple and red clasts are abundant. Matrix is medium to coarse-grained sandstone composed of various types of volcanic fragments. Note that red, oxidized volcanic fragments are more abundant in the lithic clasts and the matrix of this conglomerate compared to Unit II.

COLOR: Clasts show various colors such as dark gray, gray, pale purple, and red.

PIECES: 3-7 (23-118 cm)

Volcanic sandstone

GENERAL DESCRIPTION: Medium to coarse-grained sandstone with angular to sub-angular volcanic lithic clasts $(<0.5 \mathrm{~cm})$. The sandstone is composed of various types of basaltic and andesitic fragments, altered glass, and crystals. Towards the lower sequence, the amount of lithic clasts and the grain size of the sandstone increase. Laminations are developed. From $23-48 \mathrm{~cm}$, a fault with a dip of $85^{\circ}$ and a displacement of $7 \mathrm{~cm}$ appears. This lithology continues downward to Section 323-U1342D-12X-2.

COLOR: Dark gray to light gray 
Figure F8 (continued).

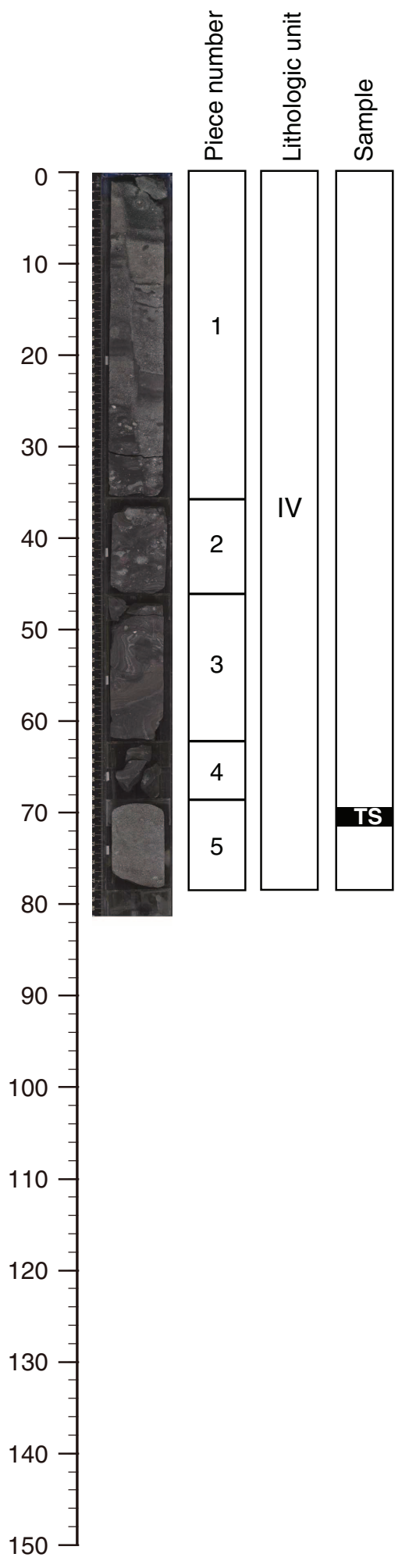

\section{Section 323-U1342D-12X-2}

UNIT IV, Interbedded volcanic sandstone and conglomerates

PIECES: 1-4 (0-69 cm)

Volcanic sandstone

GENERAL DESCRIPTION: Very fine to coarse-grained sandstone. Polymict clasts ( $\max 2 \mathrm{~cm}$, ave $1 \mathrm{~cm}$ ) make up less than $5 \%$. From 0-35 cm, a fault with a dip of $85^{\circ}$ and a displacement of $6 \mathrm{~cm}$ appears. From 48-68 cm, a slump structure is developed in dark gray sandstone with polymictic volcanic lithic clasts. COLOR: Black to dark brown

PIECE: 5 (69-78 cm)

Volcanic sandstone

GENERAL DESCRIPTION: Moderately sorted, fine to mediumgrained sandstone. The sandstone is composed of volcanic lithic fragments (sub-angular), altered glass, and crystals such as plagioclase, clinopyroxene, and magnetite. Weak parallel laminations are developed.

COLOR: Pale reddish gray 
Figure F9. Description of Core 323-U1342D-13X. (Continued on next three pages.)

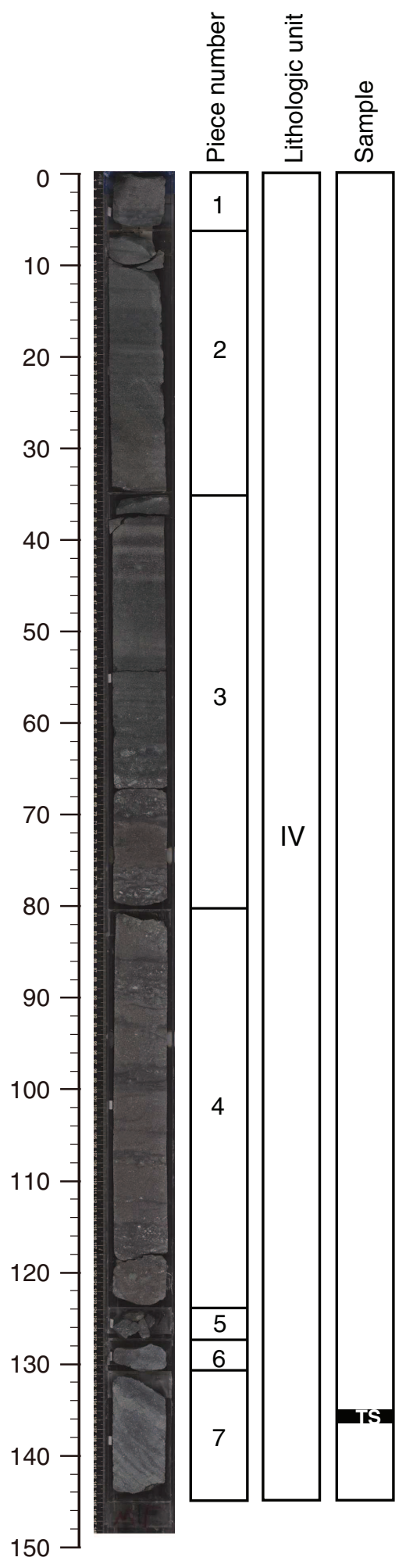

Section 323-U1342D-13X-1

UNIT IV, Interbedded volcanic sandstone and conglomerates

PIECES: $1-4(0-123 \mathrm{~cm})$

Volcanic sandstone

GENERAL DESCRIPTION: From 0-62 cm, gray to dark gray, fine to coarse sandstone appears. Parallel laminations are well developed. At the boundary at $71 \mathrm{~cm}$, the lower fine to very coarse-grained sandstone is characterized by a pale reddish gray color. The color reflects the abundant oxidized basaltic to andesitic lithic fragments. Occasionally, thin layers (ca. $0.5 \mathrm{~cm}$ thickness) of black fine to very fine sand are interbedded. Volcanic lithic clasts with angular to sub-angular shapes ( $\max 3 \mathrm{~cm}$, ave $0.3 \mathrm{~cm}$ ) are also included. This lithology is similar to the one observed in Section 323-1342D$12 X-1(40-60 \mathrm{~cm})$. At the base of this sequence $(63-70 \mathrm{~cm})$, the sandstone gradually changes to polymict conglomerate.

PIECES: $5-7(123-145 \mathrm{~cm})$

Porphyritic basalt

GENERAL DESCRIPTION: This basalt is characterized by a heterogeneous groundmass texture. Its boundary with the upper gravel sandstone has not been recovered.

COLOR: light gray to gray

\begin{tabular}{|cl|}
\hline PHENOCRYSTS & \\
Altered olivine & 2 vol\%, $<0.5 \mathrm{~mm}$ \\
Clinopyroxene & $7 \mathrm{vol} \%,<2 \mathrm{~mm}$ \\
Plagioclase & $21 \mathrm{vol} \%,<2 \mathrm{~mm}$ \\
Magnetite & $<1 \mathrm{vol} \%,<0.3 \mathrm{~mm}$ \\
VESICLES: & $6-8 \mathrm{vol} \%,<0.5 \mathrm{~mm}$ \\
GROUNDMASS: & Intersertal to intergranular texture \\
\hline
\end{tabular}


Figure F9 (continued). (Continued on next page.)

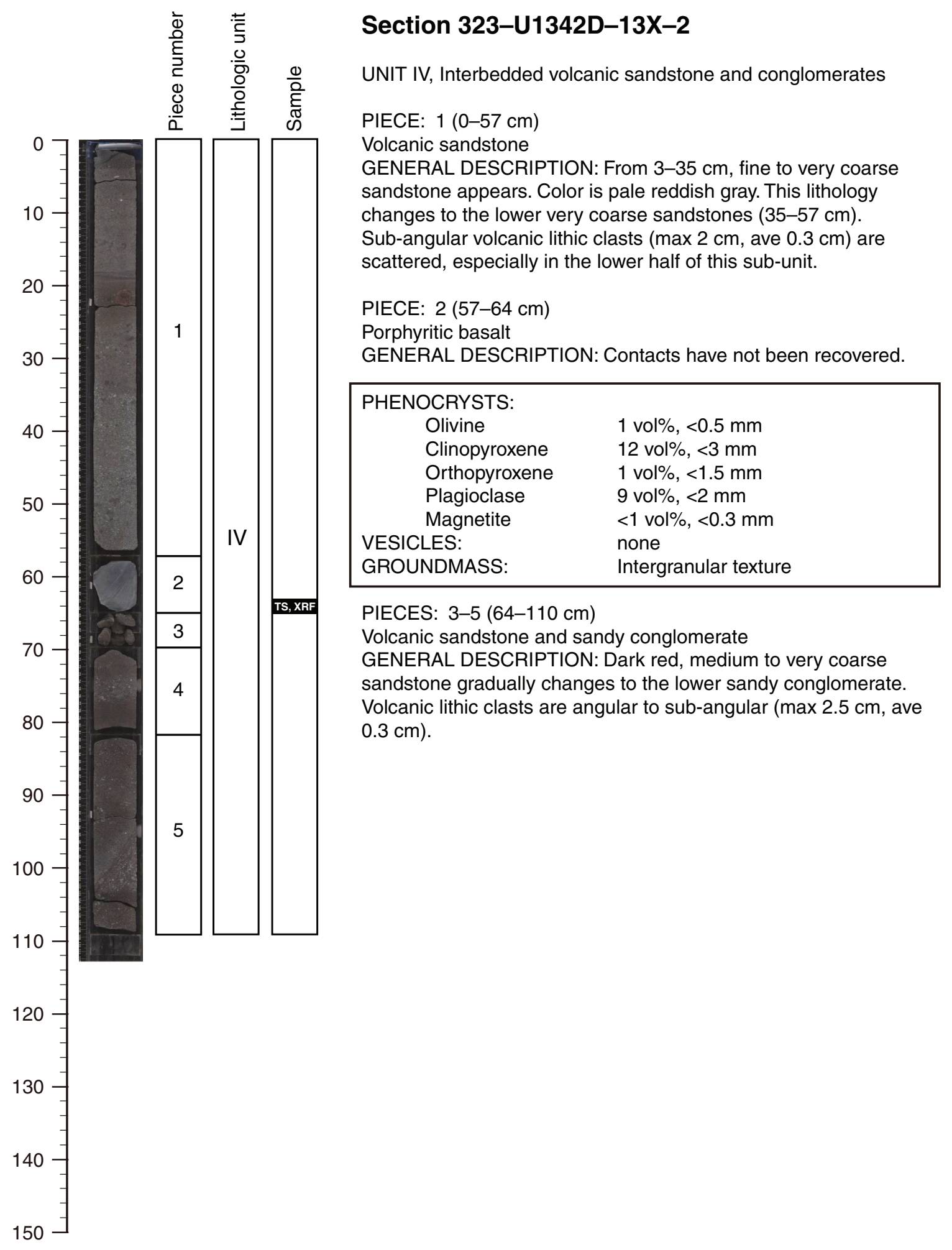


Figure F9 (continued). (Continued on next page.)

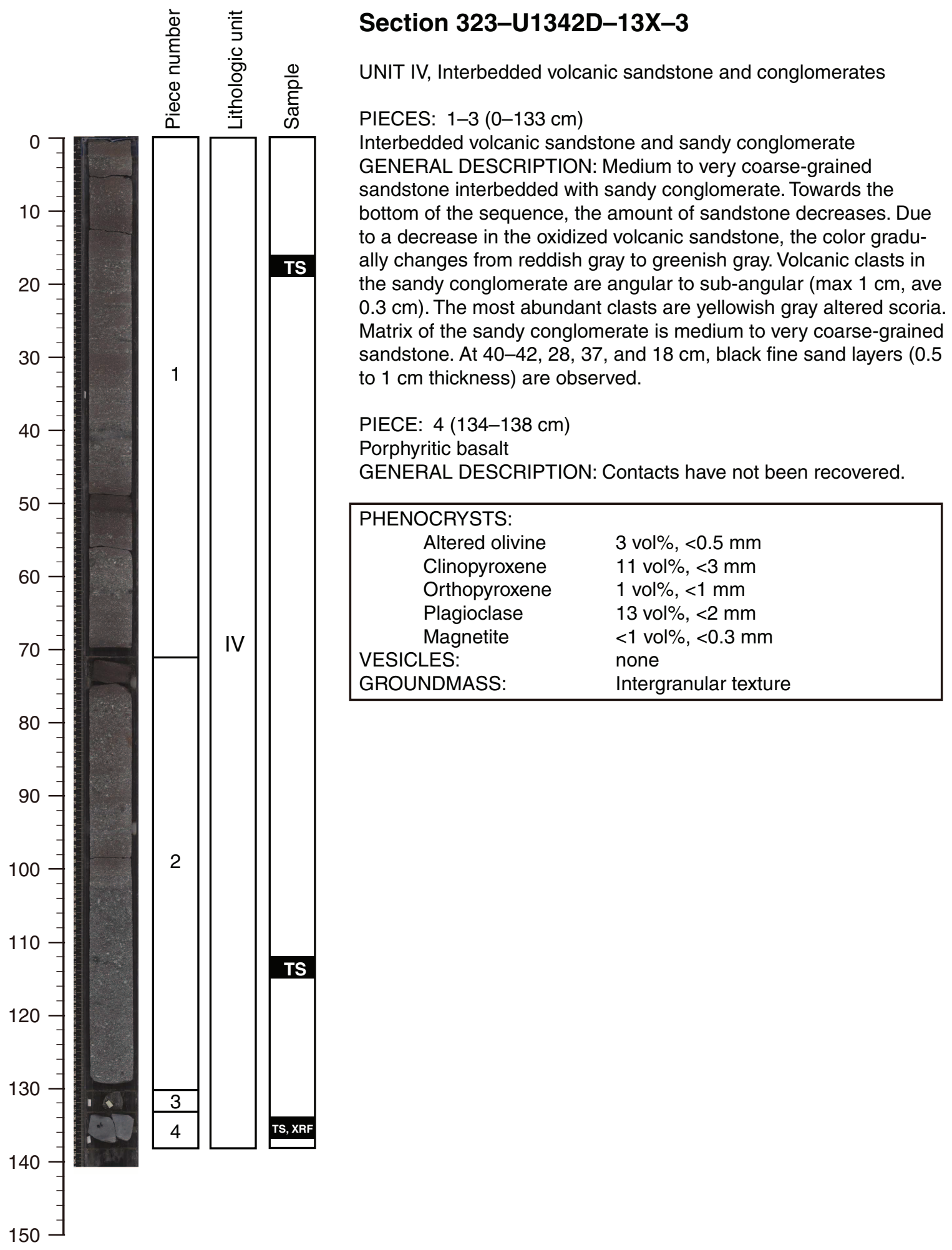


Figure F9 (continued).

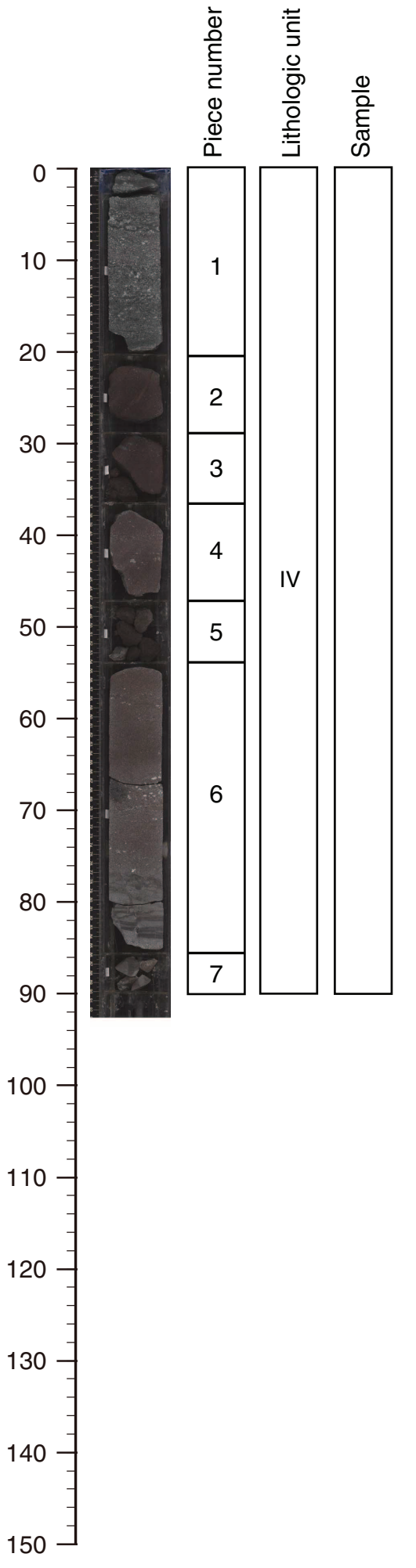

\section{Section 323-U1342D-13X-4}

UNIT IV, Interbedded volcanic sandstone and conglomerates

PIECE: $1(0-20 \mathrm{~cm})$

Volcanic sandy conglomerate

GENERAL DESCRIPTION: Polymict sandy conglomerate, showing similar lithology to that in Section 323-1342D-13X-3 (100-130 $\mathrm{cm})$. Volcanic lithic clasts are angular to sub-angular (max $1 \mathrm{~cm}$, ave $0.3 \mathrm{~cm}$ ). Most abundant clasts are yellowish gray vesiculated basalt. Matrix is medium to very coarse-grained sandstone. Contact between this sequence and the lower reddish sandstone is at 20 $\mathrm{cm}$.

COLOR: Greenish gray

PIECES: $1-7(20-86 \mathrm{~cm})$

Volcanic sandstone

GENERAL DESCRIPTION: Fine to medium-grained sandstone with weak parallel laminations. Color gradually changes from reddish gray to pale reddish gray reflecting the change in the amount of oxidized volcanic fragments. From $77-90 \mathrm{~cm}$, very fine (black) to medium (gray) sandstone with parallel laminations is faulted. The fault plane has a dip of $75^{\circ}$, and a displacement of ca. $1 \mathrm{~cm}$. Polymict volcanic lithic clasts ( $\max 1.5 \mathrm{~cm}$, ave $0.3 \mathrm{~cm}$ ) are scattered within the sandstone. This lithology continues downward to Section 323-1342D-14X-1.

COLOR: Reddish gray to pale reddish gray 
Figure F10. Description of Core 323-U1342D-14X. (Continued on next two pages.)

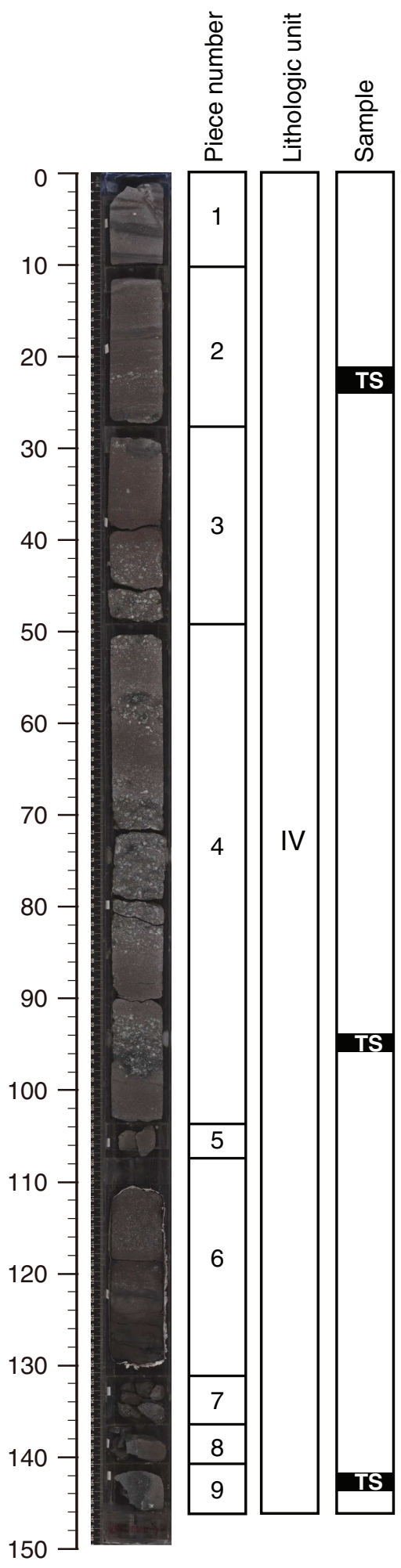

Section 323-U1342D-14X-1

Unit IV, Interbedded volcanic sandstone and conglomerates

PIECES: 1-9 $(0-146 \mathrm{~cm})$

Interbedded volcanic sandstone and sandy conglomerate GENERAL DESCRIPTION: Fine to medium-grained sandstone interbedded with sandy conglomerate. Thickness of each sandstone layer varies from 10 to $5 \mathrm{~cm}$. Sandy conglomerate is abundant from $65-100 \mathrm{~cm}$. In the upper $6 \mathrm{~cm}$, the laminated fine to mediumgrained sandstone is faulted. The fault plane dips at ca. $60^{\circ}$.

The sandstone and matrix of the sandy conglomerate are composed of oxidized reddish lithic fragments (andesitic to basaltic) and crystals (e.g., plagioclase, clinopyroxene, and magnetite). They are medium to coarse-grained.

Clasts in the sandy conglomerate are mainly composed of light gray sub-angular aphyric basaltic to andesitic fragments. They are highly vesiculated (ca. 50-70 vol\% vesicles) and include phenocrysts of plagioclase +/- clinopyroxene +/- altered olivine.

From 120-127 cm, the reddish gray sandstone gradually changes to black, very fine-grained sandstone.

COLOR: Pale reddish to black 
Figure F10 (continued). (Continued on next page.)

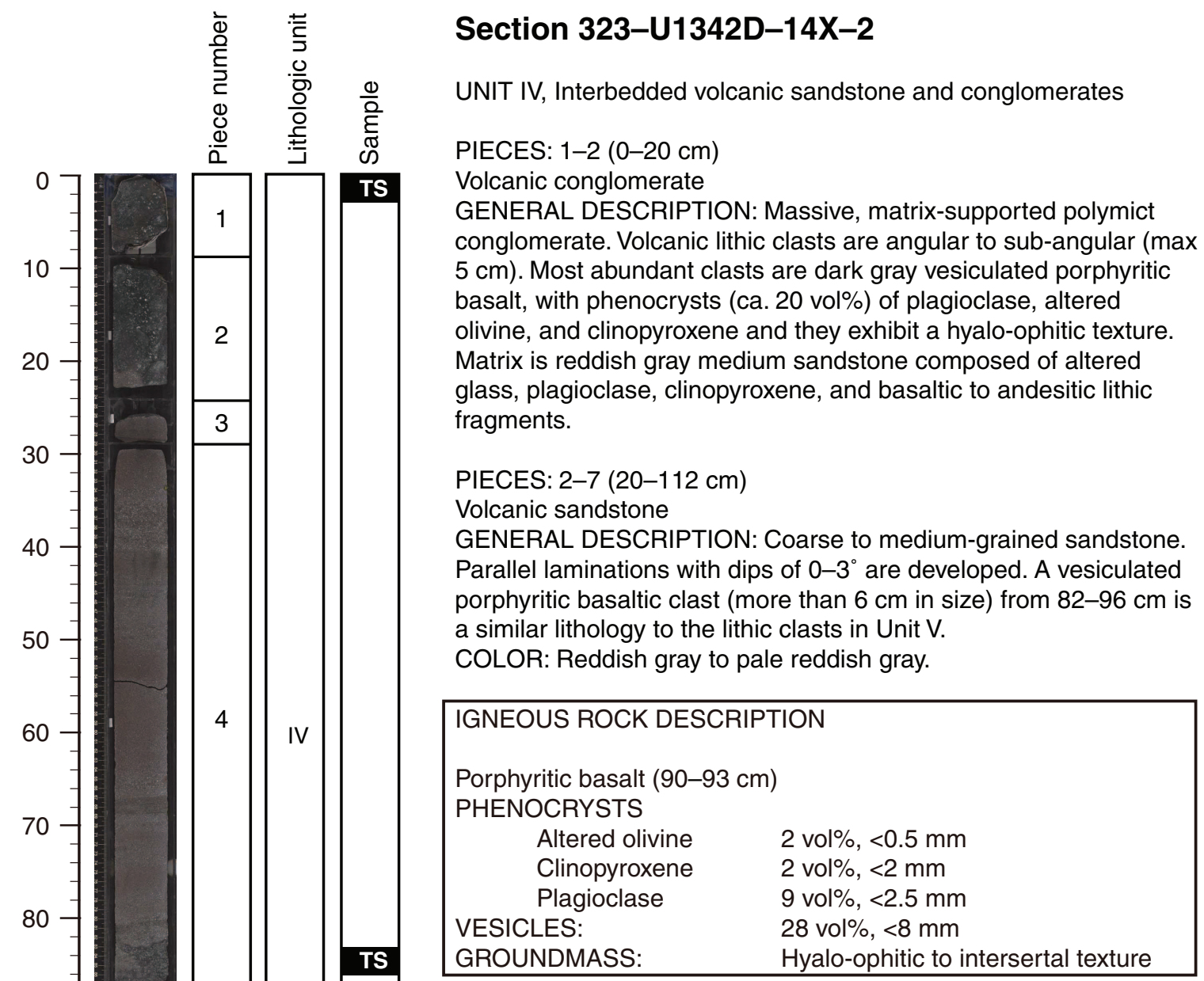

Unit V, Monomict volcanic conglomerates

PIECES: 8-10 (112-139 cm)

Vesiculated basalt

GENERAL DESCRIPTION: At $120 \mathrm{~cm}$, the boundary with the sandstone above is observed.

\begin{tabular}{|cl|}
\hline PHENOCRYSTS & \\
Altered olivine & 2 vol\%, $<0.5 \mathrm{~mm}$ \\
Clinopyroxene & $3 \mathrm{vol} \%,<2.5 \mathrm{~mm}$ \\
Plagioclase & $11 \mathrm{vol} \%,<4 \mathrm{~mm}$ \\
VESICLES: & 9 vol\%, $<5 \mathrm{~mm}$ \\
GROUNDMASS: & Intersertal texture \\
\hline
\end{tabular}

PIECE: $11(139-150 \mathrm{~cm})$

Volcanic conglomerate

GENERAL DESCRIPTION: Clasts and matrix are composed of vesiculated basalt. Phenocryst assemblage is the same as the basalt observed from 120-139 cm. This lithology continues downward to Section 323-U1342D-14X-3. 
Figure F10 (continued).

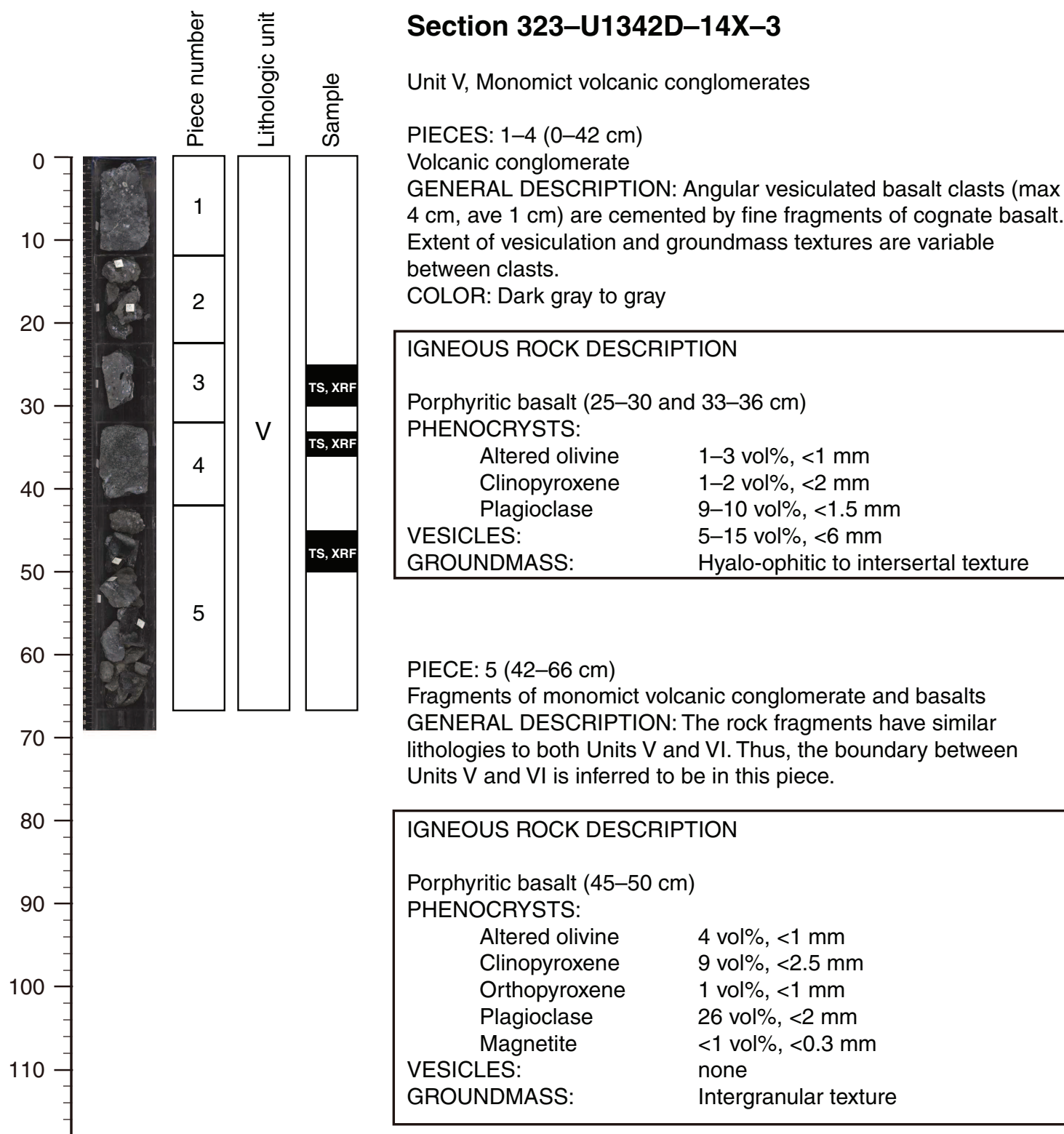


Figure F11. Description of Core 323-U1342D-15X. (Continued on next page.)

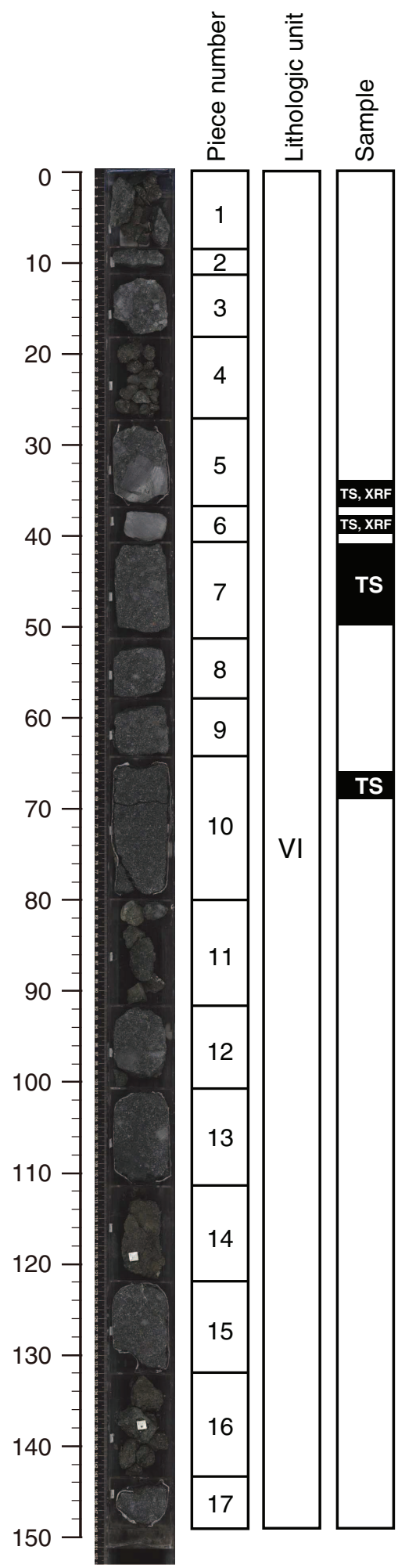

\section{Section 323-U1342D-15X-1}

UNIT VI, Polymict volcanic conglomerates

PIECES: 1-17 (0-150 cm)

Volcanic conglomerate

GENERAL DESCRIPTION: Massive, clast-supported polymict volcanic conglomerate. Lithic clasts are angular to sub-angular porphyritic basalts and andesites ( $\max >5 \mathrm{~cm}$, ave $1 \mathrm{~cm}$ ). Most abundant clasts have a phenocryst assemblage of plagioclase, altered olivine, clinopyroxene, magnetite with/without minor orthopyroxene. They show large variations in terms of groundmass texture (hyalo-ophitic to intersertal) and vesicularities (0-60 vol\%). Smaller lithic clasts $(<1 \mathrm{~cm})$ are commonly highly vesiculated $(>20$ vol\%) than larger clasts (>ca. $3 \mathrm{~cm}$ ). Note that one sub-rounded granule of hornblend-bearing andesite or dacite appears in piece 7 $(41-50 \mathrm{~cm})$. Matrix is fine to very coarse-grained sandstone composed of lithic fragments and crystals.

COLOR: Most of the clasts show gray to dark gray, but pale red clasts are also occasionally included.

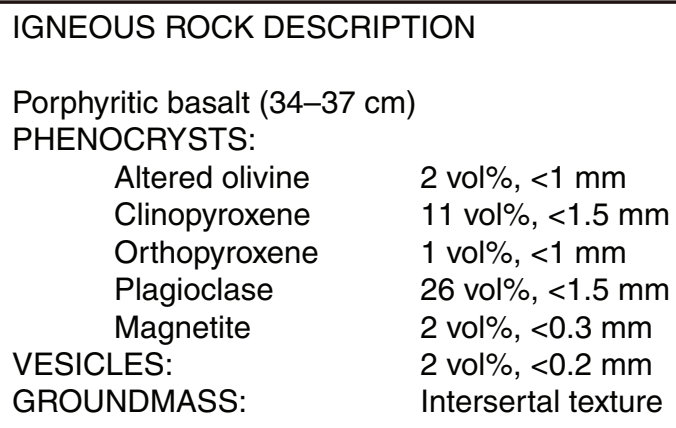

Porphyritic basalt $(38-40 \mathrm{~cm})$

PHENOCRYSTS:

Altered olivine $\quad 2 \mathrm{vol} \%,<0.5 \mathrm{~mm}$

Clinopyroxene $\quad 12 \mathrm{vol} \%,<1.5 \mathrm{~mm}$

Plagioclase $\quad 29 \mathrm{vol} \%,<1.5 \mathrm{~mm}$

Magnetite $\quad 2$ vol\%, $<0.4 \mathrm{~mm}$

VESICLES:

none

GROUNDMASS:

Intersertal texture 
Figure F11 (continued).

Section 323-U1342D-15X-2
UNIT VI, Polymict volcanic conglomerates


Figure F12. Description of Core 323-U1342D-16X. (Continued on next page.)

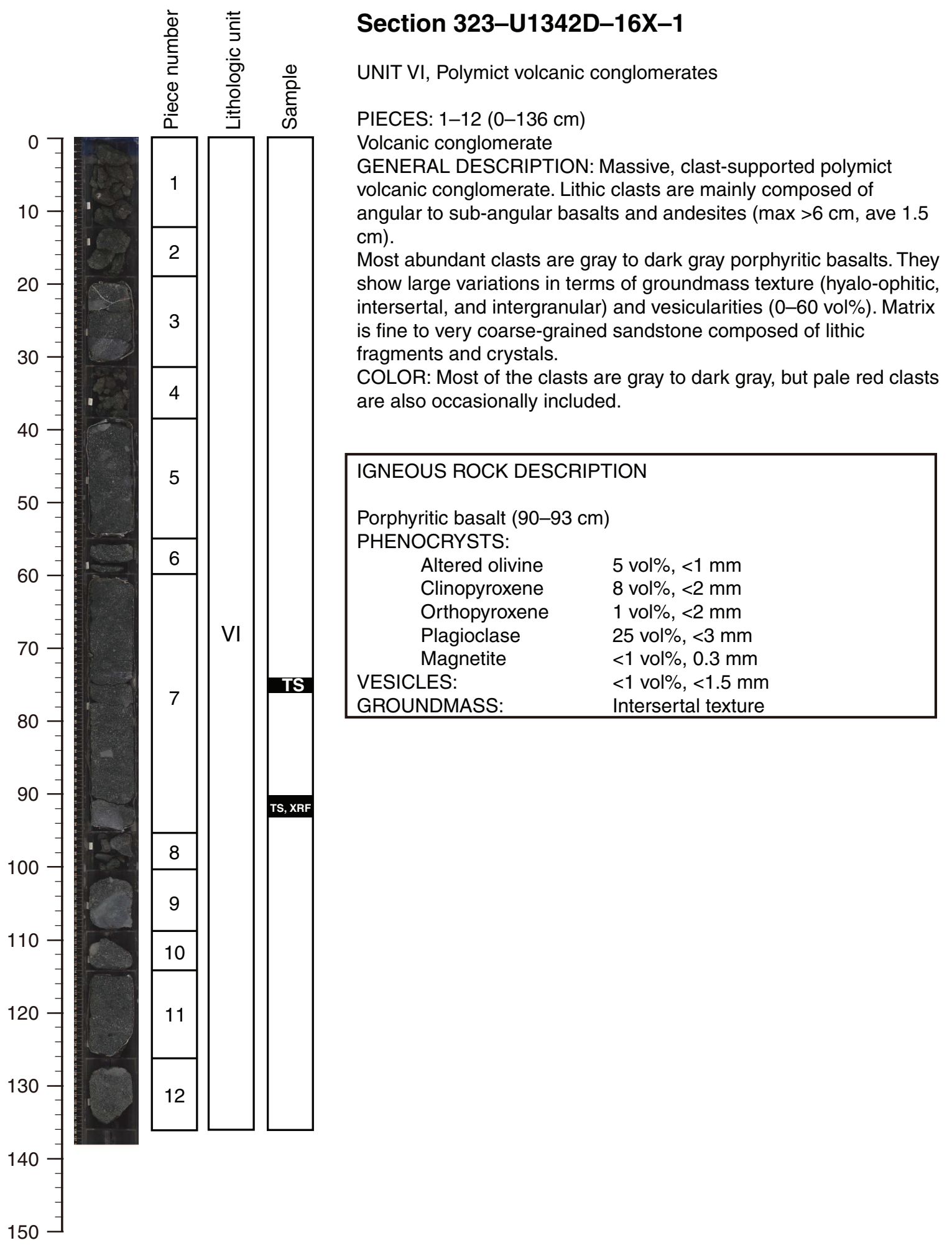


Figure F12 (continued).

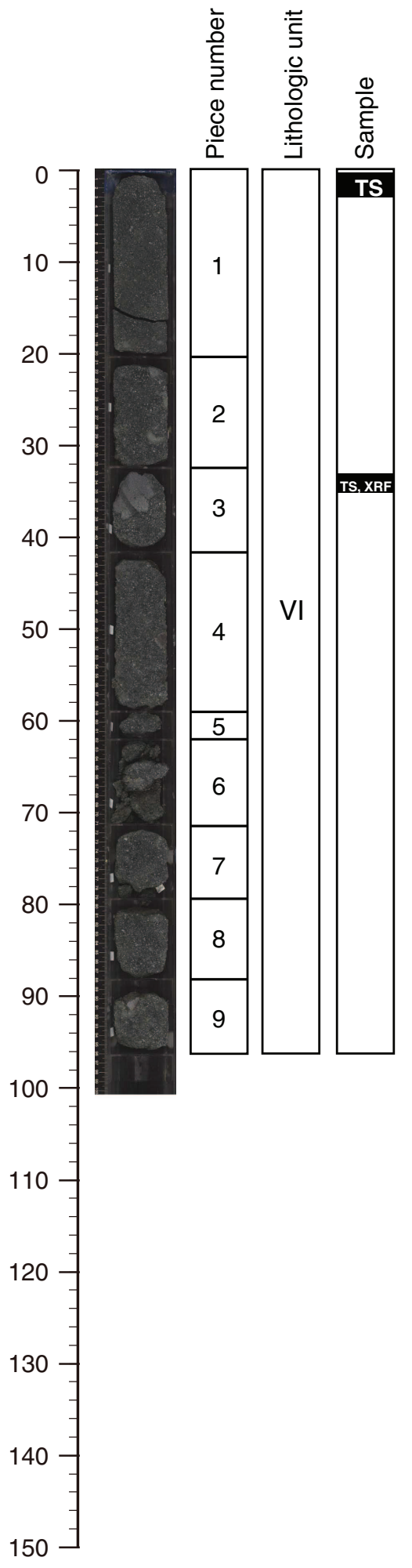

\section{Section 323-U1342D-16X-2}

UNIT VI, Polymict volcanic conglomerates

PIECES: 1-9 (0-96 cm)

Volcanic conglomerate

GENERAL DESCRIPTION: Massive, clast-supported polymict volcanic conglomerate. Lithic clasts are mainly composed of angular to sub-angular porphyritic basalts and andesites ( $\max >5$ $\mathrm{cm}$, ave $1.5 \mathrm{~cm}$ ). Lithic clasts show large variations in terms of groundmass texture (hyalo-ophitic, intersertal, and intergranular) and vesicularities (0-60 vol\%). Matrix is fine to very coarse-grained sandstone composed of lithic fragments and crystals.

COLOR: Most of the clasts are gray to dark gray, but pale red clasts are also occasionally included.

\section{IGNEOUS ROCK DESCRIPTION}

Porphyritic basalt $(33-35 \mathrm{~cm})$

PHENOCRYSTS:

Altered olivine

Clinopyroxene

Plagioclase

Magnetite

VESICLES:

GROUNDMASS:
$3 \mathrm{vol} \%,<1 \mathrm{~mm}$ $3 \mathrm{vol} \%,<2 \mathrm{~mm}$ $38 \mathrm{vol} \%,<3 \mathrm{~mm}$ $<1 \mathrm{vol} \%,<0.3 \mathrm{~mm}$ 2 vol\%, $<2 \mathrm{~mm}$ Intersertal texture 
Figure F13. Description of Core 323-U1342D-17X. (Continued on next four pages.)

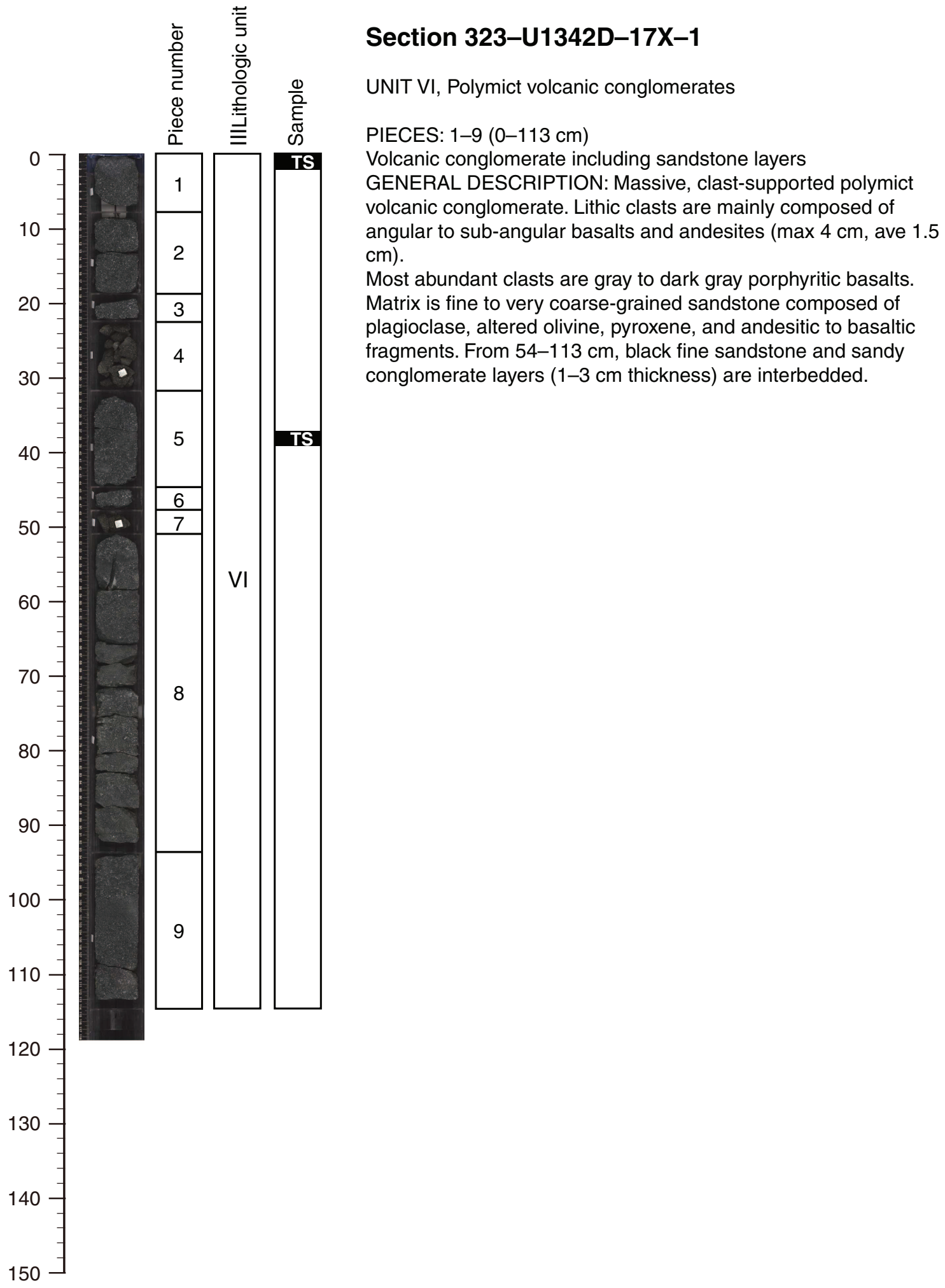


Figure F13 (continued). (Continued on next page.)

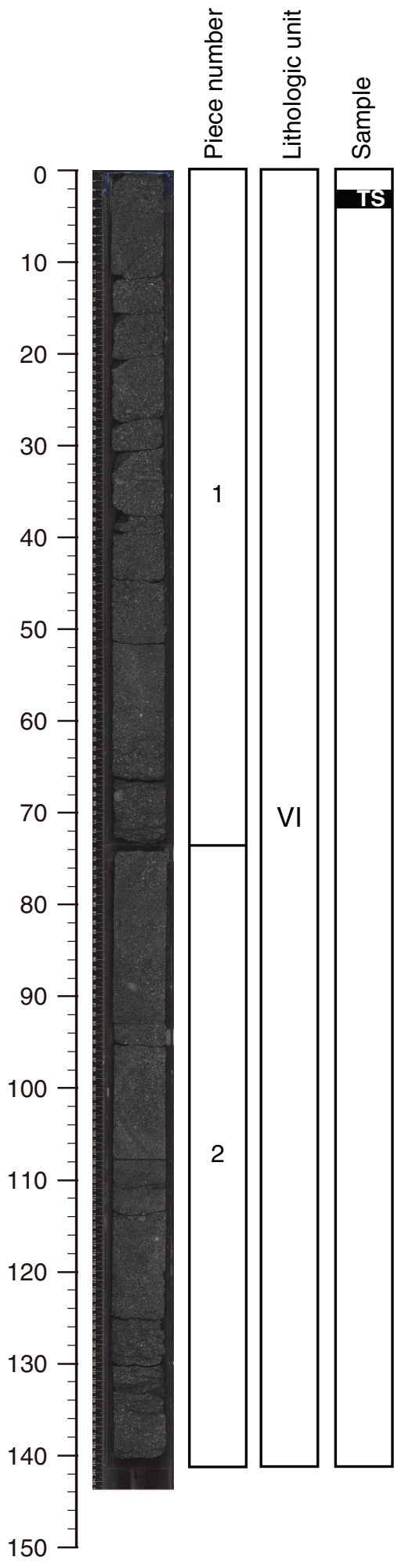

Section 323-U1342D-17X-2

Unit VI, Polymict volcanic conglomerates

PIECES: $1-2(0-140 \mathrm{~cm})$

Volcanic sandy conglomerate

GENERAL DESCRIPTION: Massive to weakly stratified sandy conglomerate. Lithic clasts are mainly composed of angular to sub-angular basalts and andesites ( $\max 1.5 \mathrm{~cm}$, ave $0.3 \mathrm{~cm}$ ). Most abundant clasts are gray to dark gray porphyritic basalt. Matrix is fine to very coarse-grained sandstone composed of crystals (plagioclase, altered olivine, pyroxene, magnetite) and andesitic to basaltic fragments. From 105-108 cm and 113-116 cm, medium dark gray sandstone layers are interbedded.

COLOR: Most of the clasts are dark gray to gray, but pale red clasts are also present. 
Figure F13 (continued). (Continued on next page.)

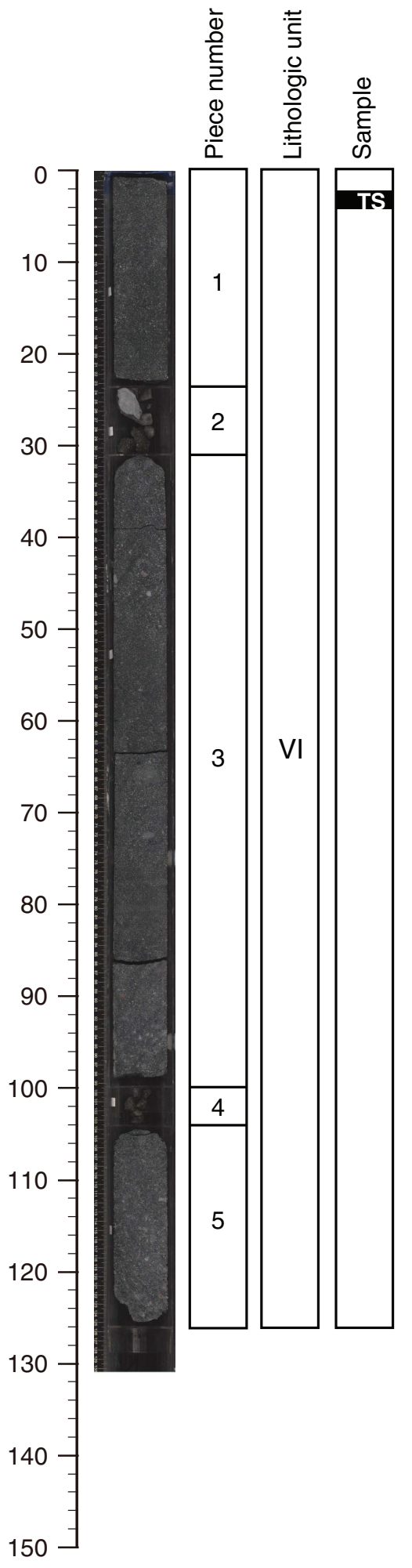

\section{Section 323-U1342D-17X-3}

UNIT VI, Polymict volcanic conglomerates

PIECES: 1-5 (0-125 cm)

Volcanic conglomerate

GENERAL DESCRIPTION: Massive polymict conglomerate. Lithic clasts are mainly composed of angular to sub-angular basalts and andesites ( $\max 2 \mathrm{~cm}$, ave $0.3 \mathrm{~cm}$ ). Most abundant clasts are gray to dark gray porphyritic basalt. Matrix is medium to very coarsegrained sandstone composed of crystals (plagioclase, altered olivine, pyroxene, magnetite) and andesitic to basaltic fragments. Thin medium to very coarse-grained sandstone layers are interbedded between 75 and $85 \mathrm{~cm}$.

COLOR: Most of the clasts are gray to dark gray, but pale red clasts are also occasionally included. 
Figure F13 (continued). (Continued on next page.)

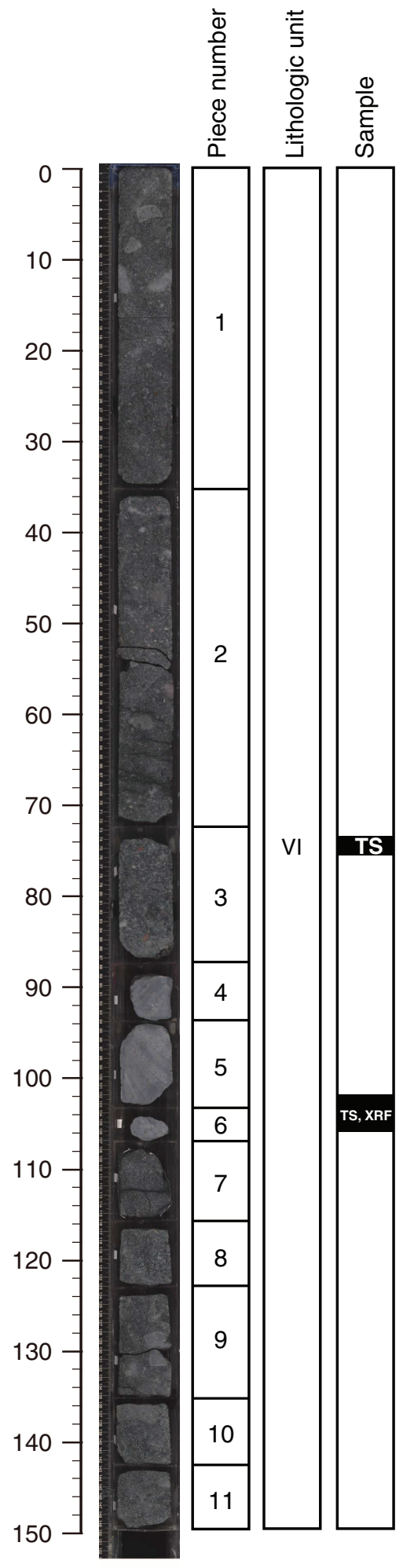

Section 323-U1342D-17X-4

UNIT VI, Polymict volcanic conglomerates

PIECES: $1-3(0-88 \mathrm{~cm})$

Volcanic conglomerate

GENERAL DESCRIPTION: Massive, clast-supported polymict volcanic conglomerate. Lithic clasts are mainly composed of angular to sub-angular basalts and andesites ( $\max 3 \mathrm{~cm}$, ave 1.5 $\mathrm{cm})$.

Most abundant clasts are gray to dark gray porphyritic basalt. Matrix is medium to very coarse-grained sandstone.

COLOR: Most of the clasts are gray to dark gray, but pale red clasts are also occasionally included.

PIECES: 4-6 (88-108 cm)

Porphyritic basalt

\section{PHENOCRYSTS: \\ Altered olivine $\quad 1-3 \mathrm{vol} \%,<1 \mathrm{~mm}$ \\ Clinopyroxene $\quad 1-2 \mathrm{vol} \%,<4 \mathrm{~mm}$ \\ Plagioclase $\quad 9-10 \mathrm{vol} \%,<2 \mathrm{~mm}$ \\ VESICLES: \\ GROUNDMASS:}

PIECES: 7-11 (108-150 cm)

Volcanic conglomerate

GENERAL DESCRIPTION: Massive, clast-supported polymict volcanic conglomerate. Lithic clasts are mainly composed of angular to sub-angular basalts and andesites $(\max >6 \mathrm{~cm}$, ave 1 $\mathrm{cm})$. Clasts are poorly sorted. Most abundant clasts are gray to dark gray porphyritic basalt. Matrix is medium to very coarse-grained sandstone.

COLOR: Most of the clasts are gray to dark gray, but pale red clasts are also occasionally included. 
Figure F13 (continued).

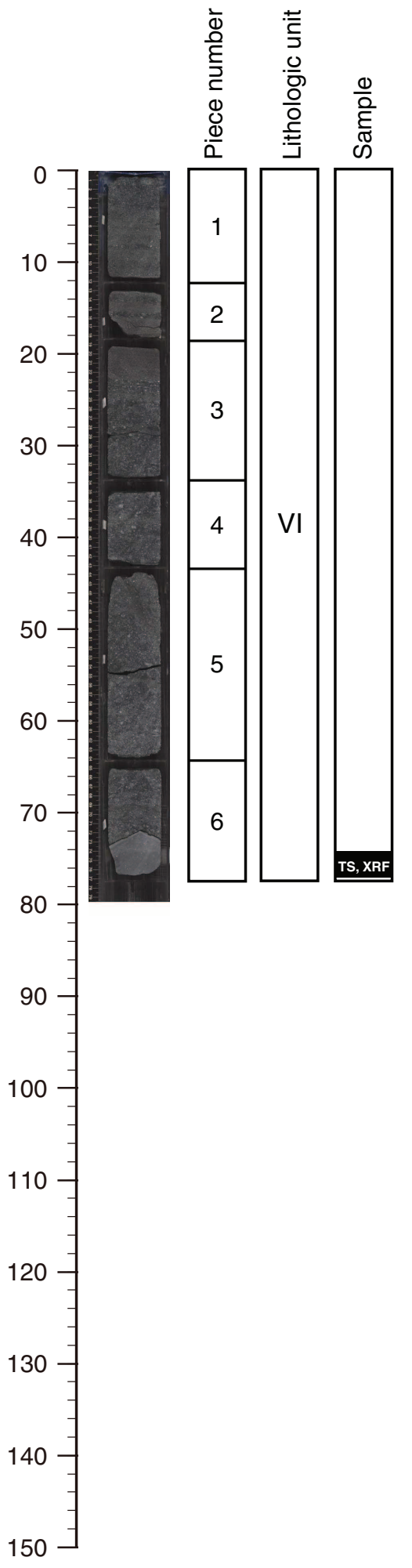

\section{Section 323-U1342D-17X-5}

UNIT VI, Polymict volcanic conglomerates

PIECES: 1-6 (30-78 cm)

Volcanic sandstone and conglomerate

GENERAL DESCRIPTION: From 0-30 cm, interbedded sandstone and conglomerate appears. The sandstone is composed of crystals and basaltic to andesitic fragments. From $30-78 \mathrm{~cm}$, massive, clast-supported polymict volcanic conglomerate appears.

Conglomerate consists of the same material as the sandstone, but a larger grain size. Lithic clasts are mainly composed of angular to sub-angular basalts and andesites ( $\max 1 \mathrm{~cm}$, ave $0.3 \mathrm{~cm}$ ). Most abundant clasts are gray to dark gray porphyritic basalt. Matrix is medium to very coarse-grained sandstone. From $72-76 \mathrm{~cm}$, a gravel of highly porphyritic basalt is included.

COLOR: The sandstone is gray to greenish gray. Clasts in the conglomerate show various colors, such as dark gray, gray, pale purple, and pale red.

\section{IGNEOUS ROCK DESCRIPTION}

Porphyritic basalt $(74-77 \mathrm{~cm})$

PHENOCRYSTS:
Altered olivine
3 vol\%, $<1 \mathrm{~mm}$
Clinopyroxene
$7 \mathrm{vol} \%,<1.5 \mathrm{~mm}$
$18 \mathrm{vol} \%,<2 \mathrm{~mm}$
$<1 \mathrm{vol} \%,<3 \mathrm{~mm}$ Intergranular texture

VESICLES:

GROUNDMASS: 
Figure F14. Description of Core 323-U1342D-18X. (Continued on next two pages.)

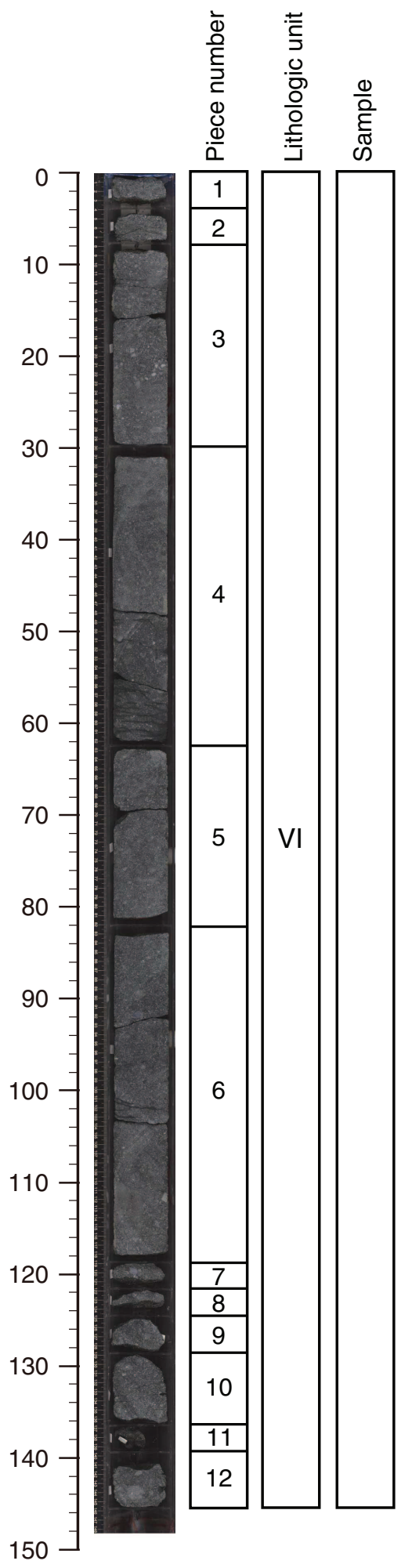

Section 323-U1342D-18X-1

UNIT VI, Polymict volcanic conglomerates

PIECES: $1-12(0-150 \mathrm{~cm})$

Volcanic sandy conglomerate and conglomerate

GENERAL DESCRIPTION: Lithic clasts are mainly composed of angular to sub-angular basalts and andesites (max $5 \mathrm{~cm}$, ave 0.5 $\mathrm{cm}$ ). Most abundant clasts are gray to dark gray porphyritic basalt. Matrix is medium to very coarse-grained sandstone.

COLOR: Most of the clasts are gray to dark gray, but pale red clasts are also occasionally included. 
Figure F14 (continued). (Continued on next page.)

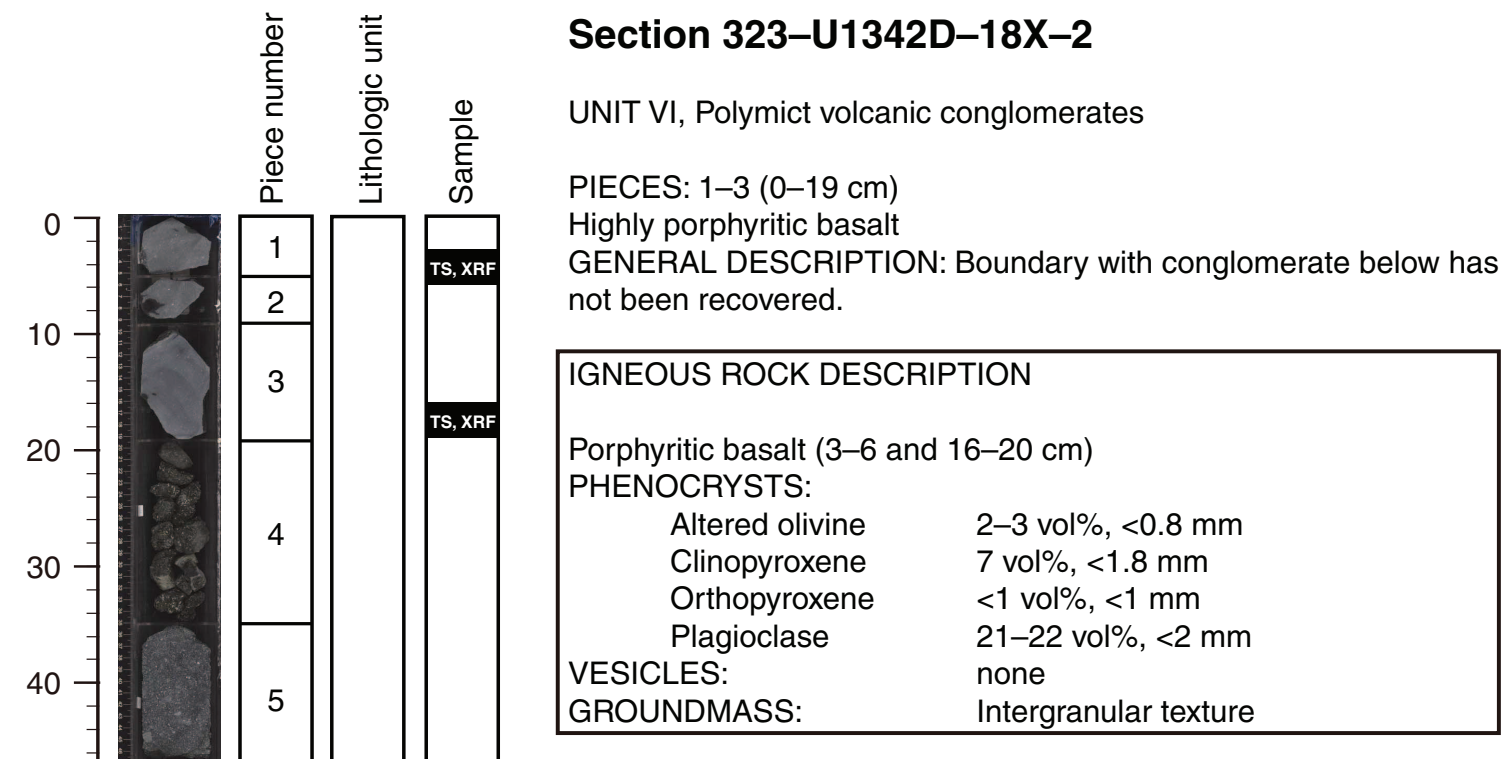

PIECES: 4-12 (19-150 cm)

Volcanic sandy conglomerate and conglomerate

GENERAL DESCRIPTION: Lithic clasts are mainly composed of angular to sub-angular basalts and andesites ( $\max 3 \mathrm{~cm}$, ave 0.4 $\mathrm{cm}$ ). Most abundant clasts are gray to dark gray porphyritic basalt. Matrix is medium to very coarse sandstone.

COLOR: Most of the clasts are gray to dark gray, but pale red clasts are also occasionally included. 
Figure F14 (continued).

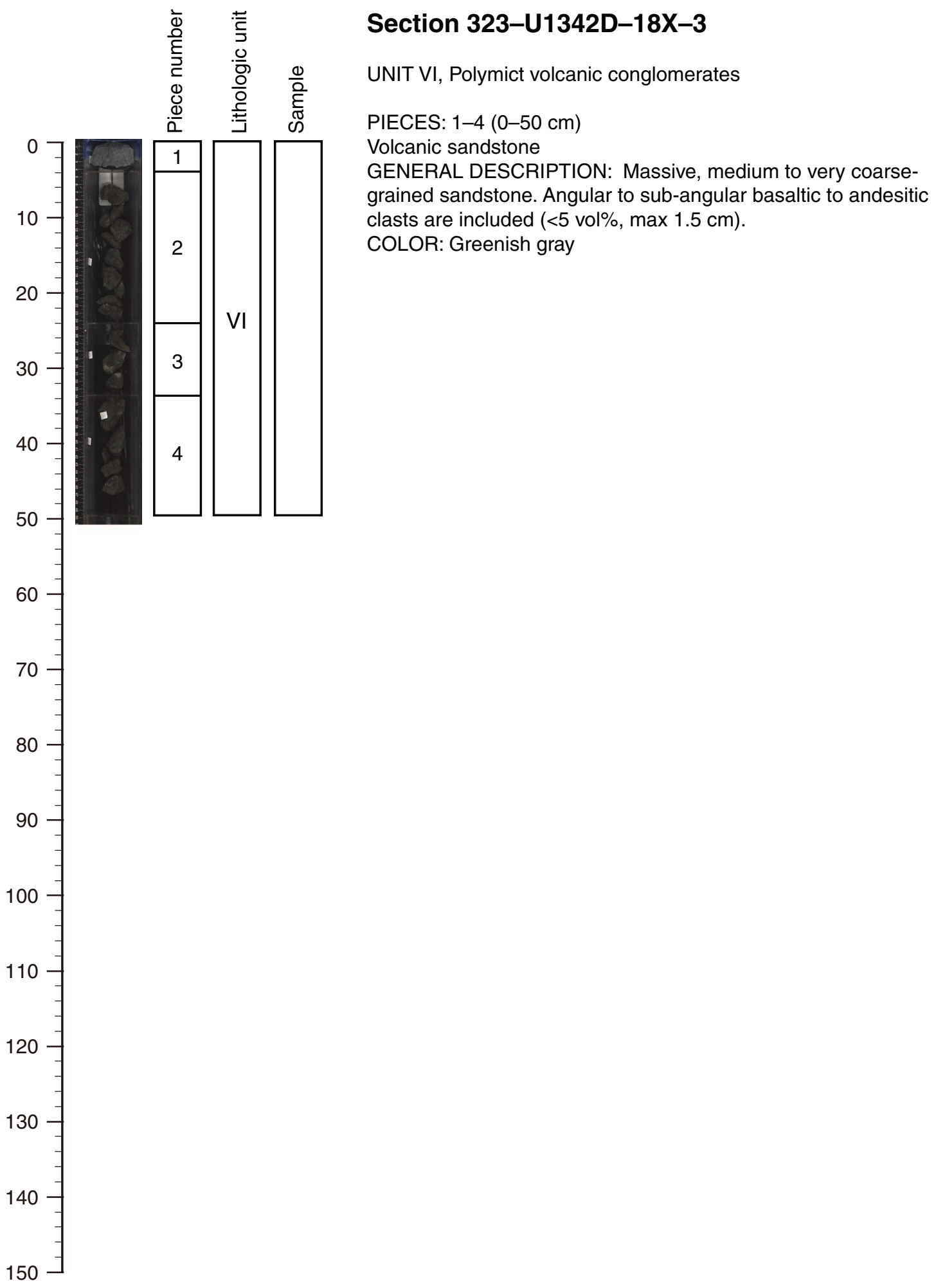


Figure F15. Description of Core 323-U1342D-19X. (Continued on next three pages.)

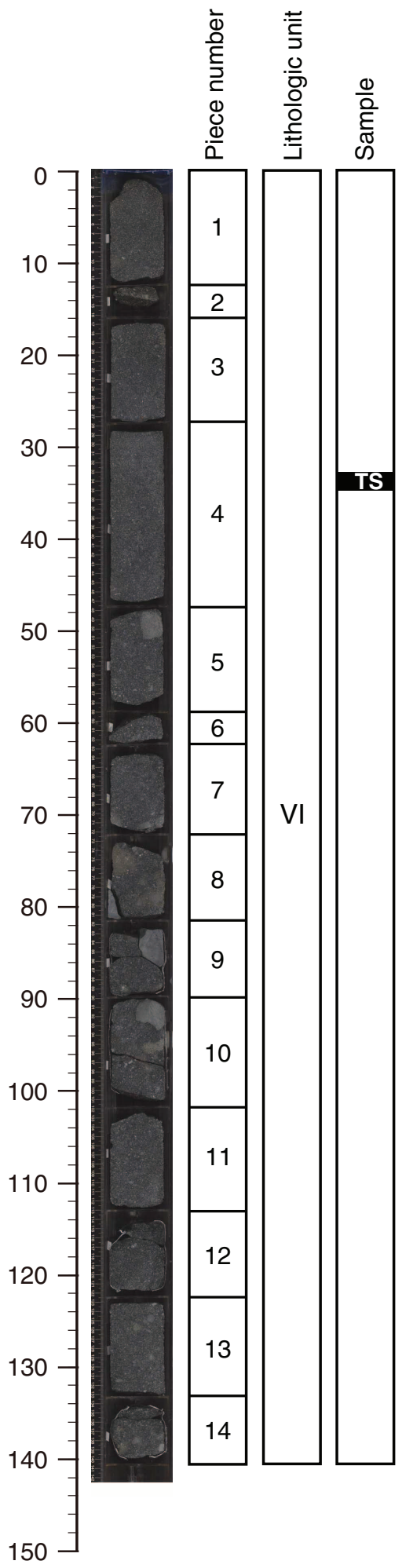

Section 323-U1342D-19X-1

UNIT VI, Polymict volcanic conglomerates

PIECES: $1-14(0-140 \mathrm{~cm})$

GENERAL DESCRIPTION: From $0-47 \mathrm{~cm}$, a very coarse to medium-grained massive sandstone with polymict clasts $(<1 \mathrm{~cm},<5$ vol\%) appears. It is dark gray in color. From $47-102 \mathrm{~cm}$, a massive polymict sandy conglomerate appears. Lithic clasts are mainly composed of angular to sub-angular basalts and andesites (max 4 $\mathrm{cm}$, ave $0.5 \mathrm{~cm}$ ). Matrix is very coarse to medium-grained, and similar to the sandstone observed from $0-47 \mathrm{~cm}$.

COLOR: Most of the clasts are gray to dark gray, but pale red clasts are also occasionally included.

From $102-140 \mathrm{~cm}$, a very coarse to medium-grained sandstone including polymictic clasts up to $1 \mathrm{~cm}$ in size appears. This lithology continues downward to Section 323-U1342D-19X-2. 
Figure F15 (continued). (Continued on next page.)

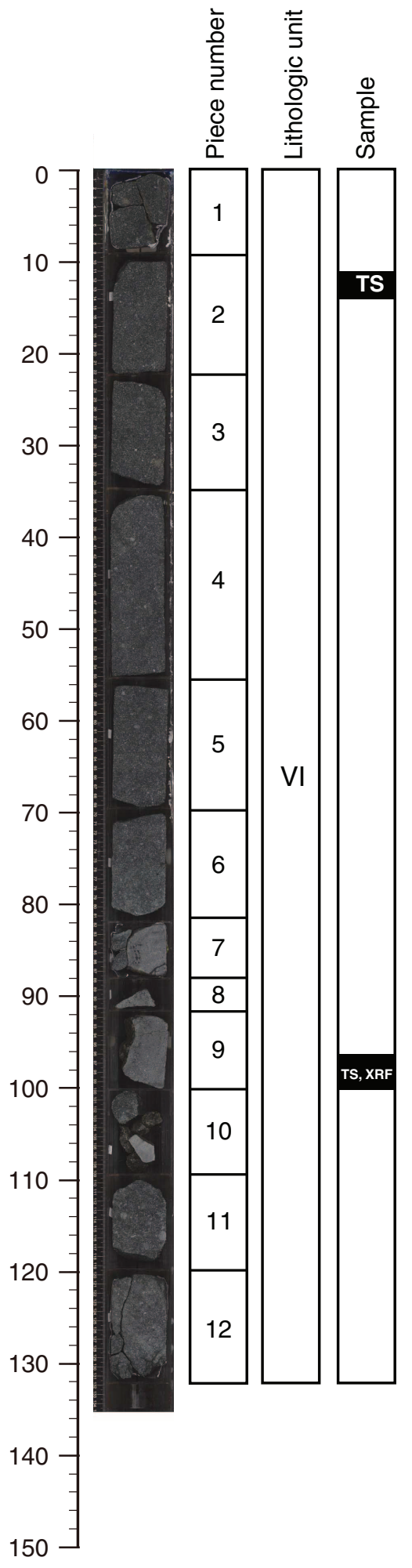

Section 323-U1342D-19X-2

UNIT VI, Polymict volcanic conglomerates

PIECES: 1-6 (0-82 cm)

Volcanic sandy conglomerate

GENERAL DESCRIPTION: Massive sandy conglomerate appears.

Sub-angular clasts of various volcanic rock types ( $\max 1 \mathrm{~cm}$, ave $0.3 \mathrm{~cm}$ ). Matrix is very coarse to medium-grained sandstone.

COLOR: Most of the clasts are gray to dark gray, but pale red clasts are also occasionally included.

PIECES: 7-9 $(82-100 \mathrm{~cm})$

GENERAL DESCRIPTION: Vesiculated highly porphyritic basalt appears as lithic clasts in conglomerate.

\section{IGNEOUS ROCK DESCRIPTION}

Porphyritic basalt $(96-100 \mathrm{~cm})$

PHENOCRYSTS:

$\begin{array}{ll}\text { Altered olivine } & 3 \mathrm{vol} \%,<0.8 \mathrm{~mm} \\ \text { Clinopyroxene } & 4 \mathrm{vol} \%,<1.5 \mathrm{~mm} \\ \text { Plagioclase } & 40 \mathrm{vol} \%,<1.5 \mathrm{~mm} \\ \text { Magnetite } & <1 \mathrm{vol} \%,<0.2 \mathrm{~mm} \\ \text { CLES: } & 12 \mathrm{vol} \%,<6 \mathrm{~mm} \\ \text { UNDMASS: } & \text { Intergranular texture }\end{array}$

PIECES: 10-12 (100-132 cm)

Volcanic sandy conglomerate

GENERAL DESCRIPTION: Massive sandy conglomerate appears. Clasts are volcanic rocks ( $\max 1 \mathrm{~cm}$, ave $0.3 \mathrm{~cm}$ ). Matrix is very coarse to medium-grained sandstone. 
Figure F15 (continued). (Continued on next page.)

Section 323-U1342D-19X-3
UNIT VI, Polymict volcanic conglomerates


Figure F15 (continued).

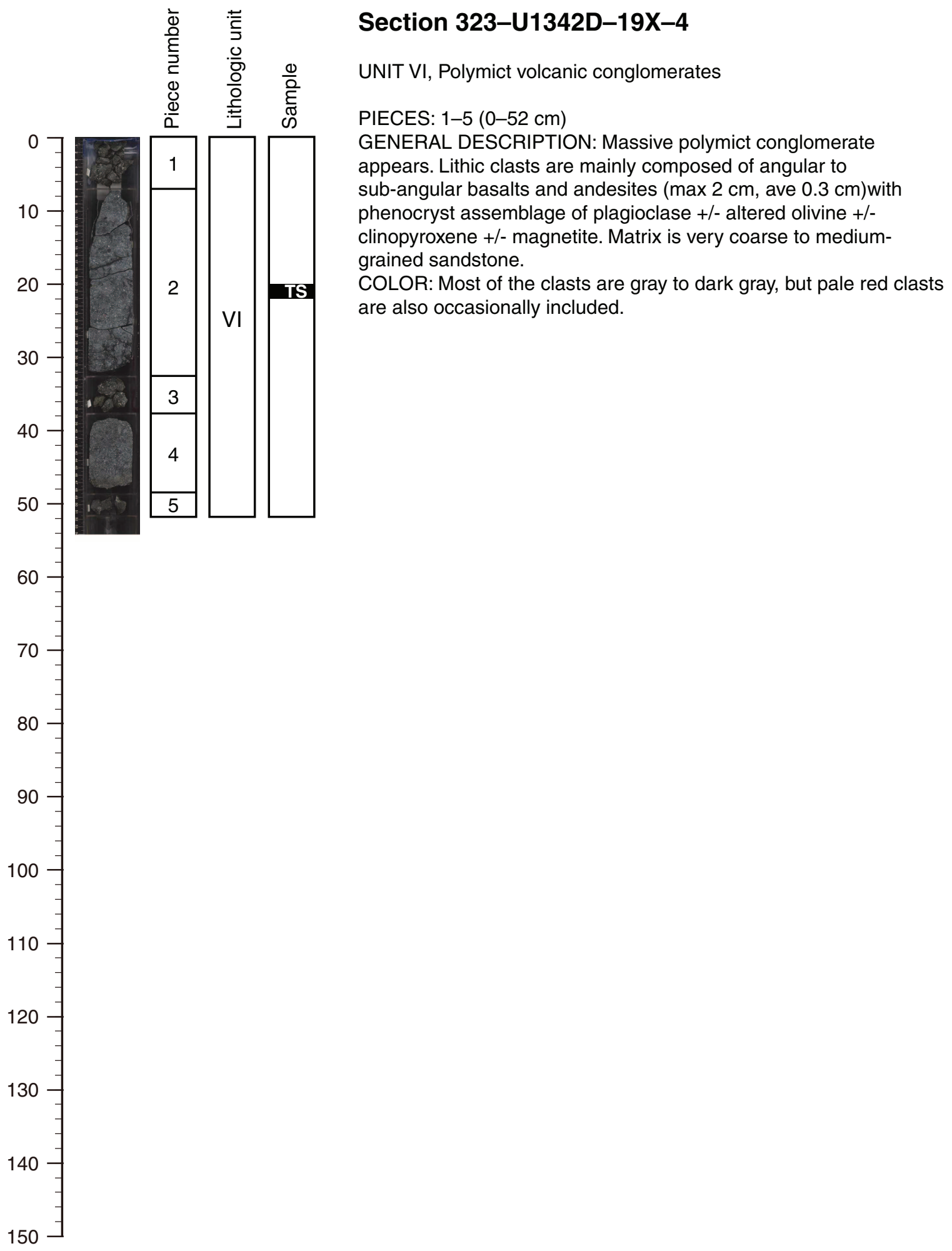

